\title{
Alpha-taxonomy in the cricetid rodent Neomicroxus, a first
} assessment

\author{
Carola Cañón ${ }^{1}$ 4*, Jenny Curay², Jorge Brito ${ }^{2}$, Javier E. Colmenares-Pinzón ${ }^{3}$, and Ulyses F. J. Pardiñas ${ }^{1,2}$ \\ ${ }^{1}$ Instituto de Diversidad y Evolución Austral (IDEAus-CONICET), Boulevard Brown 2915, PB. 9120. Puerto Madryn. Chubut, \\ Argentina. Email: carolacanonv@gmail.com (CC), ulyses@cenpat-conicet.gob.ar (UFJP). \\ ${ }^{2}$ Instituto Nacional de Biodiversidad (INABIO), Calle Rumipamba 341 y Av. de los Shyris, PB 17-07-8976. Quito. Ecuador. Email: \\ jaqui.curay@hotmail.com (JC), jorgeyakuma@yahoo.es (JB). \\ ${ }^{3}$ Grupo de Estudios en Biodiversidad, Escuela de Biología, Universidad Industrial de Santander, Carrera 27 \# 9, PB. 6344000, \\ Bucaramanga Santander. Colombia. Email: javiercolmenaresbioloogo@gmail.com (JEC-P). \\ ${ }^{4}$ Parque Real 6, Pirque, PB. 9480000 . Santiago, Chile. \\ * Corresponding author
}

Neomicroxus, a recently named genus, comprises small-bodied cricetid rodents patchily distributed in high-Andean ranges from Ecuador to Venezuela. Currently, two species of Neomicroxus are recognized, N. bogotensis, endemic to the Cordillera Oriental in Colombia and Cordillera de Mérida and Páramo de Tamá in Venezuela, and N. latebricola that occurs northern Andes of Ecuador. The genus is among the most poorly understood Neotropical rodents and to date no formal assessment about its alpha taxonomy was conducted. Based on DNA evidence of the first portion of the mitochondrial cytochrome b gene (cytb) and the first exon of the interphotoreceptor retinoid binding protein (IRBP), as well as craniodental measurements,we explored the divergence degree, genetic structure and phyletic relationships of the two species currently allocated under Neomicroxus. Our analyses support the monophyly of the genus as well as its uncertain tribal affiliation. Neomicroxus was retrieved as structured in two main branches, in agreement with the traditional recognition of two species. The populations referred to $N$. bogotensis exhibit deep divergence values $(>6 \%)$ pointing to the existence of undescribed species under its concept. In contrast, populations of $N$. latebricola show a shallow genetic structure although implying recognizable geographical breaks. A moderate degree of genetic and morphological differentiation supports a new subspecies for the western populations of $N$. latebricola. Our contribution is the first attempt to better understanding the alpha taxonomy of Neomicroxus, highlighting the importance of the geographic complexity as a barrier to the genetic flow in N. bogotensis and the significance of the subspecies concept to formalize the geographic variation recovered in N. latebricola.

Neomicroxus, un género recientemente nominado, agrupa roedores cricétidos de pequeño tamaño distribuidos en zonas altas de los Andes, desde Ecuador hasta Venezuela. Actualmente, se reconocen dos especies, N. bogotensis endémica de la Cordillera Oriental de Colombia, Cordillera de Mérida y Páramo de Tamá en Venezuela, y N. latebricola, que ocupa el norte de los Andes en Ecuador. Este género se encuentra entre los roedores neotropicales menos conocidos y, hasta la fecha, no se ha realizado ninguna evaluación formal sobre su taxonomía alfa. Basados en secuencias de ADN de la primera porción del gen mitocondrial del citocromo b (cytb) y el primer exón de la proteína de unión del interfotoreceptor del retinoide (IRBP) e información métrica cráneo-dentaria, exploramos el grado de divergencia, estructura genética y relaciones filogenéticas de las dos especies actualmente asignadas bajo Neomicroxus. Nuestros análisis apoyan la monofilia del género como así también su afiliación tribal incierta. Se recuperaron dos clados principales en concordancia con las especies reconocidas dentro del género. Las poblaciones referidas a $N$. bogotensis muestran valores de divergencia profunda ( $>6 \%$ ) que sugieren la existencia de una especie no descrita. En contraste, las poblaciones de N. latebricola muestran una estructura genética somera pero que implica quiebres geográficos reconocibles. La diferenciación genética y morfológica moderada apoyan la existencia de una nueva subespecie para las poblaciones occidentales de $N$. latebricola. Nuestra contribución es el primer intento de comprender la taxonomía alfa de Neomicroxus, destacando la importancia de la complejidad geográfica como barrera para el flujo genético en $N$. bogotensis y la importancia del concepto de subespecie para formalizar la variación geográfica observada en N. latebricola.

Keywords: Colombia; Ecuador; Microxus; Neomicroxus bogotensis; Neomicroxus latebricola.

C 2020 Asociación Mexicana de Mastozoología, www.mastozoologiamexicana.org

\section{Introduction}

Among the most poorly known high-Andean cricetids is Neomicroxus, a genus recently erected to encompass small-bodied akodont-like sigmodontines previously placed in Akodon and Microxus. Neomicroxus was based on Microxus latebricola, originally described from a single specimen collected in Ambato, on the eastern Cordillera in Ecuador (Anthony 1924). Another species, Acodon bogotensis, is also included in the genus, being up to date exclusive from Colombia and Venezuela (Alvarado-Serrano and D'Elía 2013, 2015).
Paradoxically, both species of Neomicroxus remained taxonomically unexplored, although they are abundant and easy to catch in high-Andean environments (e. g., Corporación Suna Hisca 2003; Vianchá et al. 2012; Brito 2013; Curay 2019; Ojala-Barbour et al. 2019). The deconstruction of the genus Microxus, after the peak of its complexity during the '30 (i. e., involving affinis, bogotensis, iheringi, lanosus, latebricola, mimus, and torques; Gyldenstolpe 1932), was a slow and hesitant process. As late as the beginnings of the present century, the taxonomic situation of bogotensis and latebricola was summarized by Voss (2003:21) as 
follows "This species [latebricola] closely resembles Akodon [sic] bogotensis Thomas (1895), another eastern-Andean species that was formerly referred to the genus Microxus. Among other shared similarities, both species differ from typical Akodon by their ... Although phylogenetic analyses of mitochondrial DNA sequences do not support the separate generic status of Microxus (as represented by the type species mimus Thomas; see Smith and Patton [1993] and references cited therein), sequence data from latebricola and bogotensis have not been analyzed. Despite their current generic classification, these two northern-Andean endemics clearly form a distinct clade that merits nomenclatural recognition." The advent of the first molecular data for latebricola was the keystone to crystallize what the acute morphological eye of Voss (2003) envisioned; Neomicroxus was erected with latebricola as type species (Alvarado-Serrano and D'Elía 2013). However, molecular findings retrieved an additional and previously unsuspected result; N. latebricola was neither an Akodon nor an Akodontini (Alvarado-Serrano and D'Elía 2013).

Almost nothing is known about the potential variability within Neomicroxus along the $>10^{\circ}$ degrees of latitude which encompasses its range. Both species are found in the northern Andes at elevations above 2,400 masl and reaching as high as 3,900 masl (Alvarado-Serrano and D'Elía 2015). N. bogotensis is endemic to the Cordillera Oriental of Colombia and the Cordillera de Mérida and Páramo de Tamá in Venezuela, while N. latebricola occurs to high elevations of the eastern Andes in Ecuador, from Tungurahua to Carchi provinces (Alvarado-Serrano and D'Elía 2013, 2015). Recently, Curay (2019) revealed morphological variation within the Ecuadorian populations that supports the recognition of geographic structure in what is currently understood as N. latebricola. It is in agreement with the finding of populations of the species, traditionally known and restricted only to the eastern Andes, in western locations from the Cordillera Occidental such as the Páramo de Frailejones (Brito 2013). In this contribution, we undertook a reappraisal of the systematics of Neomicroxus, including for the first time sequences of $N$. bogotensis. We analyzed two DNA markers and morphometric variables as a first attempt to explore of the alpha-taxonomy of the genus.

\section{Materials and Methods}

Sequence acquisition. We obtained DNA sequences from specimens of Neomicroxus from Colombia ( $n=3$, Cundinamarca and Santander departments) and Ecuador ( $n=2$, Carchi province; Appendix 1, Appendix 2). The new molecular data consisted of five nucleotide sequences of the first portion of the mitochondrial cytochrome b gene (cytb, $801 \mathrm{bp}$ ) and four of the first exon of the interphotoreceptor retinoid binding protein (IRBP, 1514bp). Here, we included for the first time in any phylogenetic study sequences of three specimens of Neomicroxus bogotensis. The monophyly of the genus, the identity of the sister group, and its phylogenetic position into the Sigmodontinae have not been fully corroborated (Alvarado-Serrano and D'Elía 2013). There- fore, we included sequences for representatives of the several tribes of Sigmodontinae and some outgroup taxa (other Cricetidae, Nesomyidae and Spalacidae) retrieved from GenBank. For those terminals that miss information, we completed the matrix with missing data or ambiguous state characters (i.e. N). All analyzed taxa as well as the vouchers of their cytb and IRBP sequences are listed in Appendix 2.

DNA of high molecular weight was extracted from the Ecuadorian specimens (N. latebricola) using the protocol of the Wizard Genomic DNA Purification kit, with fresh tissues as starting material. In the case of the Colombian specimens also DNA of high molecular weight was extracted from fresh tissues, as well as degraded DNA from ancient material (small fragments of rehydrated soft tissue adhered to cranial bones of museum specimens); a GeneJet Genomic DNA Purification Kit (Thermo Fisher Scientific) was used indistinctly for both processes. However, the ancient material was previously subjected to a repetitive washing protocol (Giarla et al. 2010) in order to remove foreign DNA and potential PCR inhibitors. Primer pairs used for amplification and sequencing of the mitochondrial fragment from the Ecuadorian specimens were MVZ05 and MVZ16 (Smith and Patton 1993), while for the IRBP locus we used the A1 and F1 (Jansa and Voss 2000). Amplification conditions followed Da Silva and Patton (1993) for cytb and Jansa and Voss (2000) for IRBP. For the Colombian specimens with DNA of high molecular weight (UIS-MZ 1299 and 1596), a fragment of +800 bp of the cytb was amplified with the flanking primer L14724 (Irwin et al. 1991), and the internal primer $\mathrm{O} 700 \mathrm{H}$ (Handson and Bradley 2008), while for the specimen with degraded DNA (IAvH 5777), only + 400 base pairs of the gene were amplified with the flanking primer MVZ05, and the internal primer MVZ04 (Smith and Patton 1993). For these cytb sequences we modified the amplification conditions of Hanson and Bradley (2008). The IRBP locus only was amplified from the Colombian specimens with DNA of high molecular weight using the primers IRBP217 and IRBP1351 (Stanhope et al. 1992) and we followed the amplification conditions mentioned there. All reactions included negative controls. Amplicons from Ecuadorian specimens were purified and sequenced at the external service of Macrogen, Inc. (Seoul, Korea), whereas those from Colombian specimens at the Servicio de Secuenciación y Análisis Molecular SSiGMol, Universidad Nacional de Colombia (Bogotá, Colombia).

Descriptive and phylogenetic analysis. Before conducting phylogenetic analyses, we checked the quality of each DNA sequence in the edition process with CodonCode Aligner (Codon-Code 2014). Subsequently, sequences were aligned using default options in ClustalX 2.0 (Larkin et al. 2007). New DNA sequences were deposited in GenBank (accession numbers cytb: MT240520-MT240524, IRBP: MT249797MT249800). Observed values of cytb sequence divergence ( $p$ distance) were calculated with MEGA7 (Kumar et al. 2016) ignoring those sites with missing data (Appendix 3). Phylo- 
genetic analyses were conducted using the concatenated matrix and subjected to Maximum Parsimony (MP; Farris 1982), Maximum Likelihood (ML; Felsenstein 1981) and Bayesian Inference (Bl; Huelsenbeck et al. 2001) approaches. MP analysis was carried out in PAUP* version 4.0 (Swofford 2000) with characters treated as unordered and equally weighted, 200 replicates of heuristic searches with random addition of sequences and tree bisection-reconnection (TBR) branch swapping. Nodal support was estimated by 1,000 bootstrap replicates with five replicates of sequence addition each (BT1). For the ML analysis, we used IQ-TREE version 1.6.0 software (Nguyen et al. 2015) implemented in the IQ-TREE webserver (Trifinopoulos et al. 2016) using $\mathrm{LG}+\mathrm{I}+\mathrm{G} 4$ substitution as the best-fit model. Statistical support for each individual node of the ML phylogenetic tree was estimated using 1,000 iterations of the ultrafast bootstrap value (BT2). Bayesian analyses were conducted in MrBayes 3.2 (Ronquist et al. 2012). We performed two independent runs, each with three heated and one cold Markov chains, were allowed to proceed for $10^{7}$ iterations and were sampled every 1,000 generations. We used the GTR+G+I substitution model previously determined by Akaike information criterion (AIC) in jModeltest (Posada 2008). Loglikelihood values against generation time for each run were plotted in Tracer v1.7.1 (Rambaut et al. 2018). The first 25 $\%$ of the trees obtained were discarded as burn-in, and the remaining trees were used to construct a $50 \%$ majority rule consensus tree and obtain the support for each clade as posterior probability (PP) values. Outgroups used in the phylogenetic analyses include taxa of Sigmodontinae and representatives of another rodents families (i. e., Cricetidae, Nesomyidae and Spalacidae).

Studied specimens. We examined the external and craniodental morphology of 55 specimens of Neomicroxus, including skulls, skins, and fluid-preserved animals (see Appendix 1). Studied specimens are deposited in the following insti- tutional collections: Argentina: Colección de Mamíferos del Centro Nacional Patagónico (CNP; Puerto Madryn, Chubut). Colombia: Colección de Mamíferos del Instituto de Investigación de Recursos Biológicos Alexander von Humboldt (IAvH; Villa de Leyva, Boyacá). Colección de Mamíferos "Alberto Cadena García" del Instituto de Ciencias Naturales de la Universidad Nacional de Colombia (ICN: Bogotá). Colección de Mamíferos del Museo de Historia Natural de la Universidad Industrial de Santander (UIS-MZ; Bucaramanga, Santander). Ecuador: Museo de Zoología de la Pontificia Universidad Católica del Ecuador (QCAZ; Quito). Instituto Nacional de Biodiversidad (INABIO-MECN; Quito). Instituto de Ciencias Biológicas de la Escuela Politécnica Nacional (MEPN; Quito). United States: National Museum of Natural History of Smithsonian Institute (USNM; Washington).

Morphometrics. Taking into account the important degree of hypsodonty showed by Neomicroxus, we established an ad-hoc classification composed by six tooth-wear stages (TWC, Figure 1), which based on dental wear on the cusps and the differentiation of the main structures. In this context, we considered as adults those specimens belonging to the TWC 4 to 6 . These animals were employed in morphological qualitative assessment and ulterior statistical analyses based on 18 craniodental measurements (Appendix 4), taken with a digital caliper and expressed in millimeters. For descriptive purposes, univariate statistics for each measurement were calculated. To perform a multivariate exploration, we used a sample composed by 12 specimens of $N$. bogotensis and 21 of $N$. latebricola (sexes pooled) as input data for a principal component analysis (PCA; Johnson and Wichern 1999; Carleton and Musser 1989). Raw data were standardized by transformation to their natural logarithms and the first three principal components were calculated on the resultant covariance matrix. To test the potential variation of $N$. bogotensis through its range, we added to the analysis several Venezuelan speci-

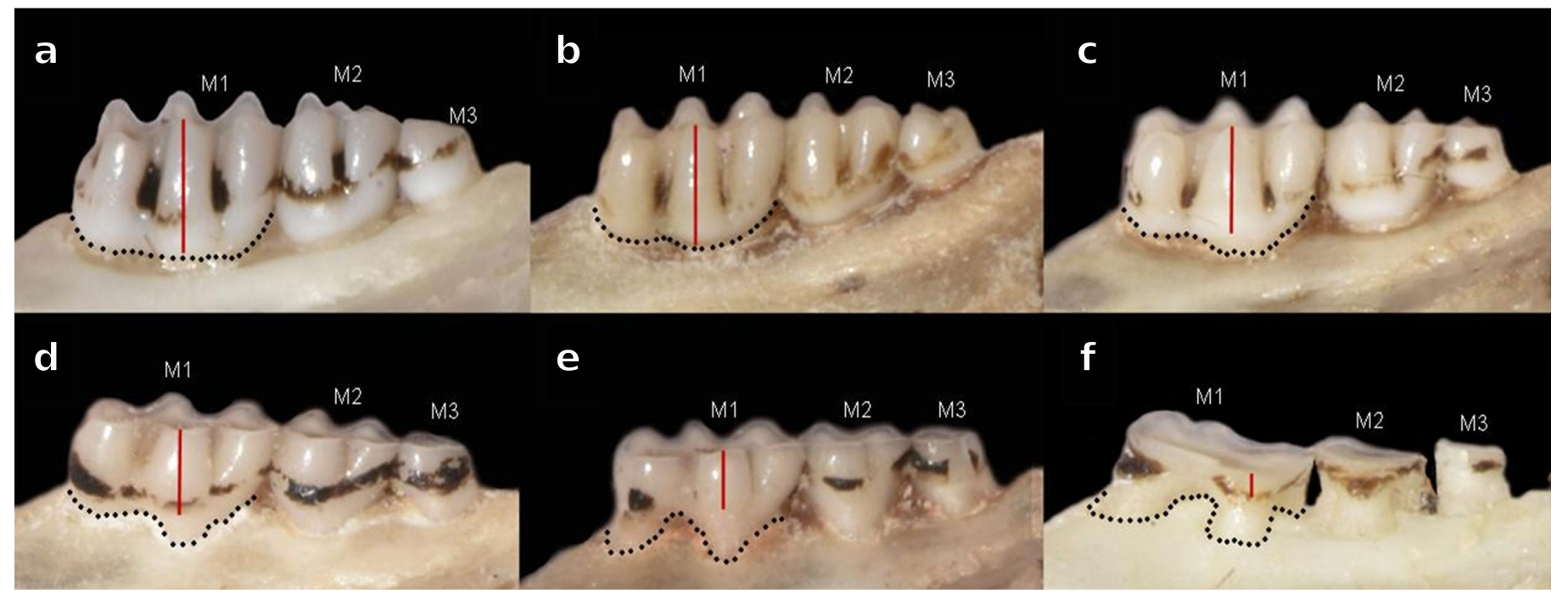

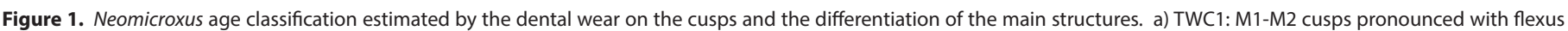

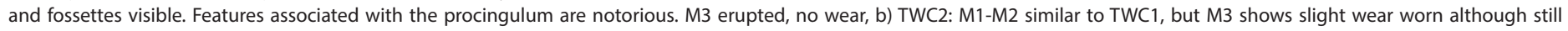

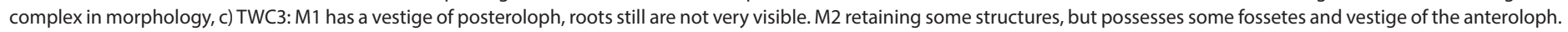

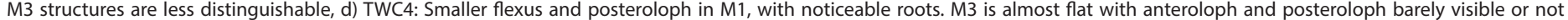

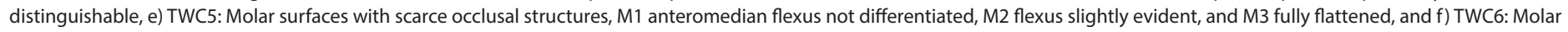
surfaces without occlusal structures, roots very visible. M3 is totally worn, clearly exposing the dentin. 
mens (Mérida and Táchira states) with incomplete measurements because they were assessed with a different goal by the senior author. For this reason and to avoid calculations with missing data, we reduced the number of variables considered to eight (ONL, BZP, LD, LIF, LM1-3, BB, CIL, IML), and worked on a matrix composed by 12 individuals. For $N$. latebricola, the PCA was executed with 21 individuals and 18 variables (Appendix 3). Additionally, to assess the differentiation between the molecular recovered groups, we perform a Discriminant Analysis (DA) employing the same log-transformed data removing missing values ( 25 individuals, 16 variables). Group assignments were validated by a jackknife resampling. For all morphometrical analyses, we used the free software Past version 4.0 (Hammer et al. 2001).

\section{Results}

Phylogenetic relationships and genetic divergence. Phylogenetic analyses recovered well-resolved topologies within Oryzomyalia (sensu Steppan et al. 2004), with tribal relationships mostly concordant with previous studies (e. g., Alvarado-Serrano and D'Elía 2013; Salazar-Bravo et al. 2016; Gonçalves et al. 2018). The genus Neomicroxus was found to be monophyletic with high support values (Figure 2a; BT1/ BT2/PP = 99/99/1.0), but without affiliation to any recognized tribe in the MP and BI topologies, and sister to Abrotrichini + Wiedomyini in the ML analysis but weakly supported. In all approaches (MP, ML, and BI), two major clades strongly supported were retrieved within the genus. One clade is formed by individuals from Colombia (100/96/0.9) and can be referred to what is currently understood as $N$. bogotensis; another clade is represented by sequences from
Ecuadorian Cordillera Oriental and Occidental (100/74/0.9), and can be confidently associated to N. latebricola. The overall mean divergence at the cytb gene for Neomicroxus reaches $6.3 \%$, meanwhile, the genetic distance between the two main clades is $11 \%$ (see Appendix 3 ). In the bogotensis clade, the phyletic relationships show a profound divergence between individuals from Santander and Cundinamarca departments (> $6 \%$ ). Our sampling is insufficient to evaluate the demography of the species, however, the analyzed localities are geographically close, so we can affirm that the divergence observed between northern and central (Cundinamarca) Colombia is not due to a phenomenon of isolation by distance. This deep divergence (also reflected in the branch lengths), suggests that the populations of $N$. bogotensis here analyzed are older, possibly demographically stable, with a strong barrier (geographical or ecological) that interrupts gene flow.

On the other hand, within the latebricola clade, we recovered a shallow genealogy with two minor groups or subclades which diverge by $1.4 \%$. One subclade is composed of the same haplotype shared by QCAZ4160 and QCAZ4167 individuals, both from the Ecuadorian Napo province. Meanwhile the other subclade groups three different haplotypes, slightly divergent, from Carchi (MECN3727/MECN3734, QCAZ9801) and Napo (QCAZ4121) provinces (Appendix 3). Conversely to the observed variation in N. bogotensis, the genealogical relationships and the divergence values between and within N. latebricola subclades reveal the existence of current genetic flow between populations, reflected by the lack of reciprocal monophyly between the provinces, which also is a sign of populations in the process of expansion.

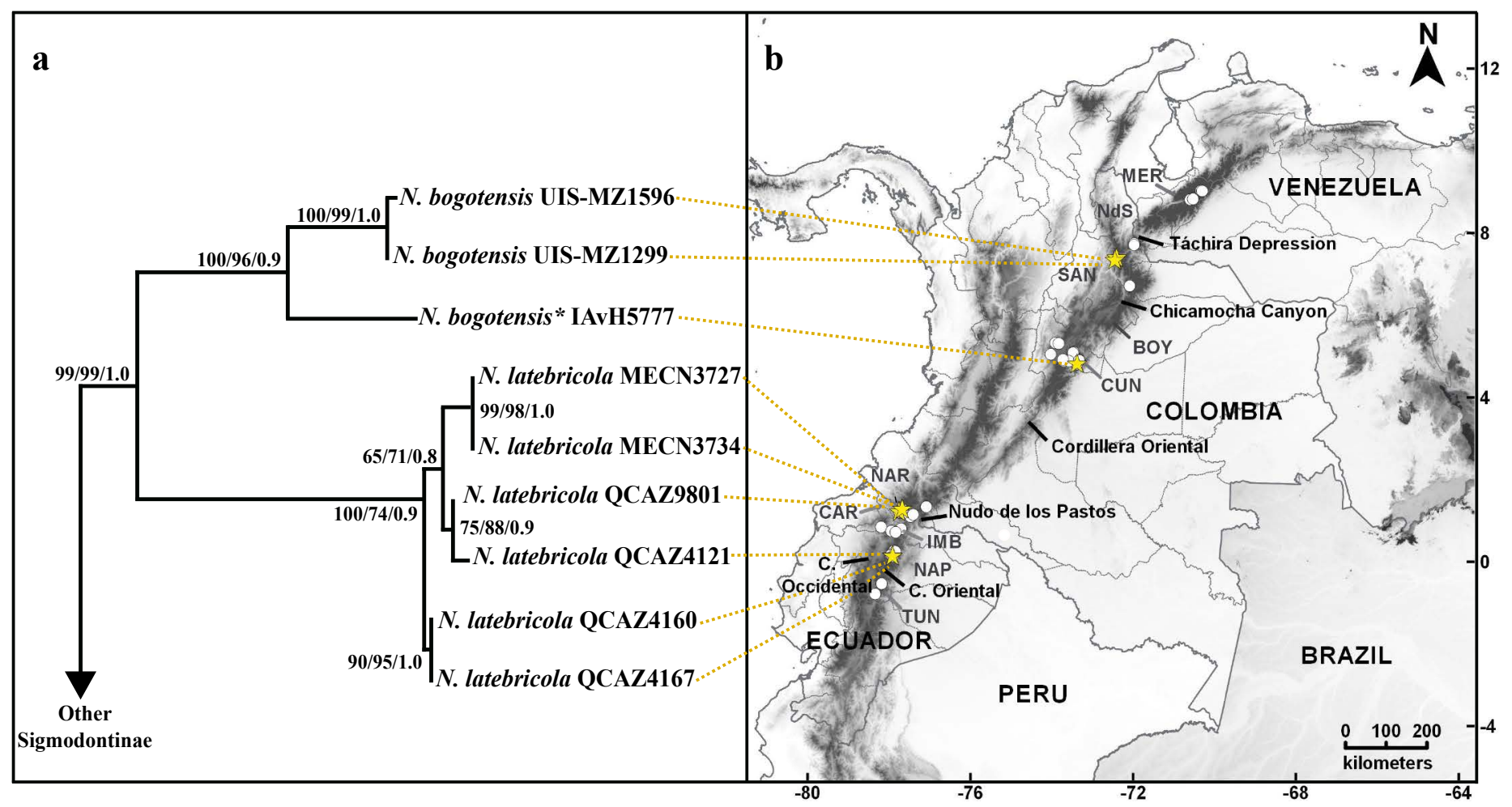

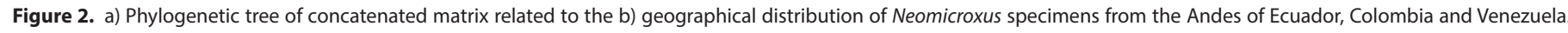
Support values (MP/ML/BI) are indicate next to each node. Yellow stars indicate specimens used in the phylogenetic analyses. 
Morphometric analyses. The univariate morphometric analysis reveals little differences among the samples, being $N$. bogotensis who possesses lower values to several of the craniodental variables here recorded (Table 1). The PCA for $N$. bogotensis showed a clear separation between specimens from north of Colombia (Santander and Norte de Santander departments), Cundinamarca, and Venezuela (Figure 3). The $88.6 \%$ of the total variation is summarized in the first two principal components, none of which can be interpreted as a size factor because they include positive and negative coefficients for some variables (Table 2). The largest contribution of the first component is attributed to the follow- ing variables: breadth of zygomatic plate, length of incisive foramina, length of upper diastema, occipitonasal length, while for the PC2 are the lengths of incisive foramina and the upper diastema. The N. latebricola PCA retrieves two partially overlapping groups from the Cordillera Oriental (Napo province) and Occidental (Carchi province; Figure 3). These results are congruent with the molecular results (see above); $77.2 \%$ of the variation is explained by the PC1-2. The craniodental variables with the greatest contribution are the breadth of incisive foramina and breadth of the bony palate on the PC1, and breadth of zygomatic plate and length of incisive foramina on the PC2 (Table 2).

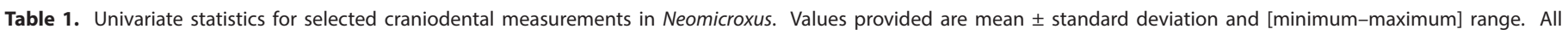
measurements are expressed in millimeters.

\begin{tabular}{|c|c|c|c|c|c|}
\hline & $\begin{array}{c}\text { N. Iatebricola } \\
\text { Occidente } \\
n=13\end{array}$ & $\begin{array}{c}\text { N. Iatebricola } \\
\text { Oriente } \\
n=9\end{array}$ & $\begin{array}{c}\text { N. bogotensis North } \\
\text { Colombia } \\
n=3\end{array}$ & $\begin{array}{c}\text { N. bogotensis } \\
\text { Cundinamarca } \\
\qquad n=1\end{array}$ & $\begin{array}{c}\text { N. bogotensis } \\
\text { Venezuela } \\
n=9\end{array}$ \\
\hline Occipitonasal length - ONL & $\begin{array}{c}25.53 \pm 0.4 \\
{[24.95-26.21]}\end{array}$ & $\begin{array}{c}25.18 \pm 0.22 \\
{[24.89-25.65]}\end{array}$ & $\begin{array}{c}23.52 \pm 0.71 \\
{[22.75-24.14]}\end{array}$ & 24.33 & $\begin{array}{c}23.18 \pm 0.39 \\
{[22.49-23.74]}\end{array}$ \\
\hline Condylo-incisive length - CIL & $\begin{array}{c}23.18 \pm 0.49 \\
{[22.49-23.91]}\end{array}$ & $\begin{array}{c}22.62 \pm 0.24 \\
{[22.15-22.93]}\end{array}$ & $\begin{array}{c}20.57 \pm 0.67 \\
{[19.9-21.24]}\end{array}$ & 21.45 & $\begin{array}{c}20.43 \pm 0.31 \\
{[20.03-21.14]}\end{array}$ \\
\hline Greatest zygomatic breadth - ZB & $\begin{array}{c}11.97 \pm 0.15 \\
{[11.73-12.34]}\end{array}$ & $\begin{array}{c}12.04 \pm 0.12 \\
{[11.82-12.21]}\end{array}$ & --- & 11.67 & $\begin{array}{c}11.25 \pm 0.21 \\
{[11.01-11.56]}\end{array}$ \\
\hline Interorbital breadth - IB & $\begin{array}{c}4.70 \pm 0.1 \\
{[4.41-4.87]}\end{array}$ & $\begin{array}{l}4.82 \pm 0.12 \\
{[4.69-5.06]}\end{array}$ & $\begin{array}{l}4.45 \pm 0.19 \\
{[4.25-4.63]}\end{array}$ & 4.75 & --- \\
\hline Breadth of zygomatic plate - BZP & $\begin{array}{c}1.39 \pm 0.06 \\
{[1.3-1.5]}\end{array}$ & $\begin{array}{c}1.38 \pm 0.1 \\
{[1.26-1.52]}\end{array}$ & $\begin{array}{c}1.33 \pm 0.04 \\
{[1.29-1.37]}\end{array}$ & 1.67 & $\begin{array}{c}1.36 \pm 0.1 \\
{[1.23-1.54]}\end{array}$ \\
\hline Length of upper diastema - LD & $\begin{array}{c}6.26 \pm 0.19 \\
{[6-6.68]}\end{array}$ & $\begin{array}{c}6.38 \pm 0.2 \\
{[6.09-6.74]}\end{array}$ & $\begin{array}{c}5.75 \pm 0.16 \\
{[5.58-5.9]}\end{array}$ & 6.01 & $\begin{array}{c}5.6 \pm 0.13 \\
{[5.39-5.83]}\end{array}$ \\
\hline Breadth of bony palate - BBP & $\begin{array}{l}5.39 \pm 0.1 \\
{[5.24-5.6]}\end{array}$ & $\begin{array}{c}5.36 \pm 0.09 \\
{[5.26-5.51]}\end{array}$ & $\begin{array}{l}5.24 \pm 0.35 \\
{[4.99-5.64]}\end{array}$ & 5.59 & --- \\
\hline Length of incisive foramina - LIF & $\begin{array}{c}4.75 \pm 0.18 \\
{[4.44-5]}\end{array}$ & $\begin{array}{c}4.73 \pm 0.25 \\
{[4.46-5.15]}\end{array}$ & $\begin{array}{l}4.12 \pm 0.71 \\
{[3.3-4.56]}\end{array}$ & 4.5 & $\begin{array}{c}3.97 \pm 0.14 \\
{[3.76-4.17]}\end{array}$ \\
\hline Breadth of incisive foramina - BIF & $\begin{array}{c}1.66 \pm 0.1 \\
{[1.55-1.84]}\end{array}$ & $\begin{array}{l}2.02 \pm 0.14 \\
{[1.83-2.2]}\end{array}$ & $\begin{array}{c}1.76 \pm 0.13 \\
{[1.62-1.85]}\end{array}$ & 1.87 & --- \\
\hline Length of maxillary toothrow - LM1-3 & $\begin{array}{c}3.63 \pm 0.1 \\
{[3.41-3.83]}\end{array}$ & $\begin{array}{c}3.5 \pm 0.13 \\
{[3.26-3.69]}\end{array}$ & $\begin{array}{c}3.46 \pm 0.06 \\
{[3.42-3.53]}\end{array}$ & 3.73 & $\begin{array}{c}3.57 \pm 0.09 \\
{[3.43-3.69]}\end{array}$ \\
\hline Breadth of first upper molar - BM & $\begin{array}{l}1.17 \pm 0.04 \\
{[1.08-1.25]}\end{array}$ & $\begin{array}{c}1.12 \pm 0.04 \\
{[1.03-1.17]}\end{array}$ & $\begin{array}{l}1.14 \pm 0.09 \\
{[1.04-1.2]}\end{array}$ & 1.15 & --- \\
\hline Breadth of palatal bridge - BPB & $\begin{array}{c}2.65 \pm 0.16 \\
{[2.46-3.1]}\end{array}$ & $\begin{array}{c}2.99 \pm 0.17 \\
{[2.75-3.31]}\end{array}$ & $\begin{array}{l}2.68 \pm 0.49 \\
{[2.29-3.23]}\end{array}$ & 3.13 & --- \\
\hline Length of nasals - LN & $\begin{array}{l}10.11 \pm 0.16 \\
{[9.66-10.27]}\end{array}$ & $\begin{array}{c}10.1 \pm 0.12 \\
{[9.87-10.24]}\end{array}$ & $\begin{array}{c}9.24 \pm 0.37 \\
{[8.84-9.58]}\end{array}$ & 9.52 & --- \\
\hline Breadth of braincase - BB & $\begin{array}{c}11.65 \pm 0.20 \\
{[11.21-11.96]}\end{array}$ & $\begin{array}{c}11.65 \pm 0.15 \\
{[11.28-11.79]}\end{array}$ & $\begin{array}{c}10.93 \pm 0.37 \\
{[10.53-11.25]}\end{array}$ & 11.26 & $\begin{array}{c}11.11 \pm 0.21 \\
{[10.72-11.38]}\end{array}$ \\
\hline Breadth of the occipital condyles - BOC & $\begin{array}{l}6.14 \pm 0.12 \\
{[5.92-6.39]}\end{array}$ & $\begin{array}{l}6.14 \pm 0.09 \\
{[6.04-6.3]}\end{array}$ & $\begin{array}{l}5.82 \pm 0.24 \\
{[5.55-5.98]}\end{array}$ & 5.77 & --- \\
\hline Zygomatic internal length - ZIL & $\begin{array}{l}7.03 \pm 0.17 \\
{[6.75-7.36]}\end{array}$ & $\begin{array}{c}7.08 \pm 0.1 \\
{[6.85-7.18]}\end{array}$ & --- & 6.61 & --- \\
\hline Mandibular length - ML & $\begin{array}{c}12.76 \pm 0.33 \\
{[11.98-13.25]}\end{array}$ & $\begin{array}{c}13.04 \pm 0.37 \\
{[12.6-13.59]}\end{array}$ & $\begin{array}{c}11.41 \pm 0.29 \\
{[11.19-11.74]}\end{array}$ & 12.15 & --- \\
\hline Mandibular molar toothrow length - IML & $\begin{array}{c}3.8 \pm 0.08 \\
{[3.63-3.94]}\end{array}$ & $\begin{array}{c}3.65 \pm 0.13 \\
{[3.43-3.78]}\end{array}$ & $\begin{array}{c}3.77 \pm 0.03 \\
{[3.74-3.79]}\end{array}$ & 3.87 & $\begin{array}{l}3.77 \pm 0.11 \\
{[3.63-3.9]}\end{array}$ \\
\hline
\end{tabular}


a) Neomicroxus bogotensis

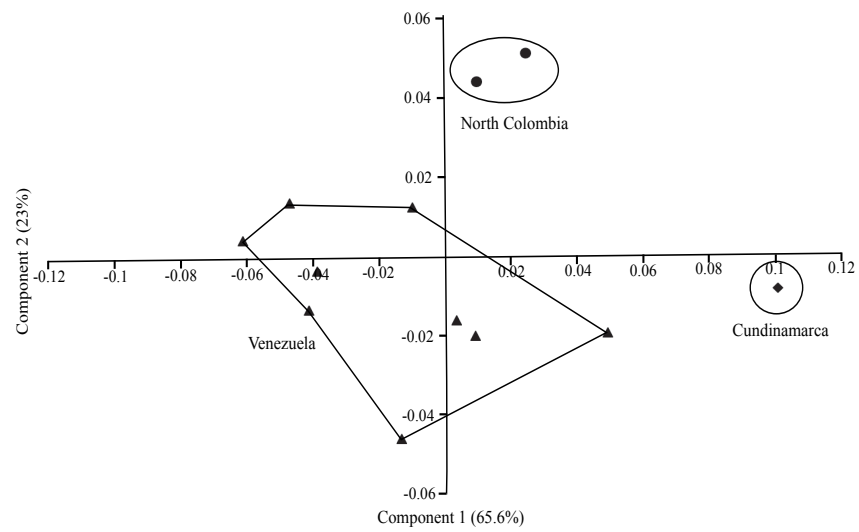

b) Neomicroxus latebricola

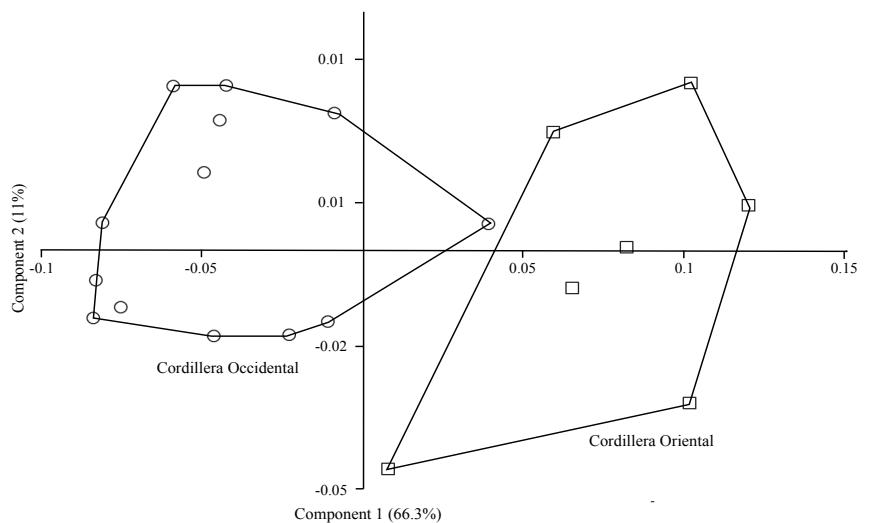

Figure 3. Principal component analysis, components 1 and 2 , of the 8 log-transformed craniodental measurements for in $N$. bogotensis $(n=12)$, and 18 for $N$. latebricola ( $n=21)$. $\$$.

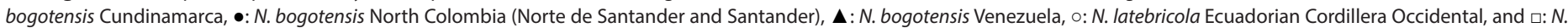
latebricola Ecuadorian Cordillera Oriental.

The Discriminant Analysis confirms the separation of $N$. bogotensis from the north of Colombia (i.e. Norte de Santander and Santander departments) and the specimen of Cundinamarca department. Similarly, the samples of N. latebricola from the Oriental and Occidental cordilleras of Ecuador are clearly differentiated (Figure 4). For both species, the recovered groups are completely concordant with the molecular arrangements. According to jackknife resampling, the predefined groups (i.e. N. bogotensis: North Colombia [Norte de Santander and Santander departments], Cundinamarca, and Venezuela [Mérida], $N$. latebricola: Ecuadorian Cordillera Oriental and Occidental ) are correctly classified in a $72 \%$ when Venezuela is excluded, and a $70 \%$ when it is included (Appendix 5). The variables which most contributed to the discrimination among these groups were the interorbital breadth, breadth of bony palate, breadth of incisive foramina, and breadth of first upper molar.

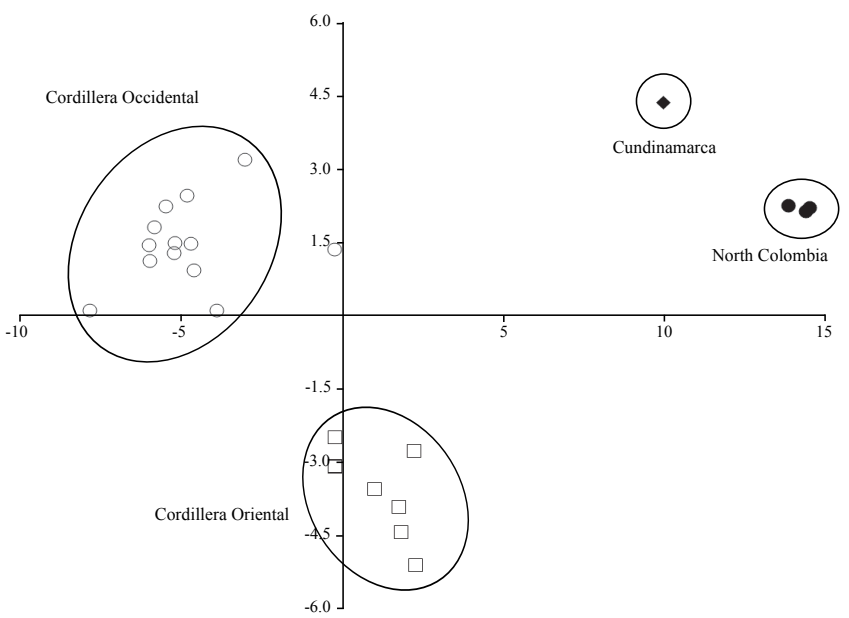

Figure 4. $\mathrm{P}$ Plot of canonical discriminant analysis based on 16 craniodental measurements from Colombian and Ecuadorian specimens of Neomicroxus. $\bullet$ : bogotensis Cundinamarca, •: N. bogotensis North Colombia (Norte de Santander and Santander), ०: N. latebricola Ecuadorian Cordillera Occidental, and $\square$ : N. latebricola Ecuadorian Cordillera Oriental.

\section{Discussion}

Neomicroxus uniqueness and phylogeny. The distinction of Neomicroxus as a new entity was based on molecular data from a few specimens of $N$. latebricola, cemented with a shallow morphological review at generic level, mostly pointed to disconnect Neomicroxus from Akodon (Alvarado-Serrano and D'Elía 2013). Since then, only Curay (2019) ventured to evaluate the variability of $N$. latebricola studying several populationa samples in Ecuador. This approach highlighted the occurrence of $N$. latebricola in western locations from the cordillera Occidental, a finding previously reported by Brito (2013; overlooked in Alvarado-Serrano and D'Elía 2015) and revealed unsuspected geographical variation.

Despite these findings, the non-inclusion of N. bogotensis in a formal phylogenetic analysis has limited the confirmation of hypothesis advanced by Voss (2003) and Alvarado-Serrano and D'Elía (2013) about the generic status of Neomicroxus. The monophyly of Neomicroxus is not an unsuspected result since both species have been traditionally considered very close due to morphological similarity (Voss 2003). In turn, the novelty molecular data for $N$. bogotensis, added to those of N. latebricola, strengthens the consideration that the genus does not appear closely related to any other lineage, placing Neomicroxus as a Sigmodontinae incertae sedis (Alvarado-Serrano and D'Elía 2013). This finding invites to the recognition of a new clade on Andean rodents with tribal rank.

An additional issue is to explain the differential genealogical structure detected in each species of Neomicroxus, suggesting contrasting evolutionary histories. Probably, it could be linked with differential environmental conditions in the northern Andes along the Neogene that could promote the spatial structuring. Judged as a whole, the range of Neomicroxus shows an important gap in southern Colombia (Figure 2b). If this "lagoon," which turns sharply allopatric both species, is artefactual or real is debatable. Colombian southernmost portions to the Ecuadorian bor- 
Table 2. Results of the principal component analysis based on measurements of Neomicroxus specimens. Scheme and names of taken measurements are illustrated in the Supporting information S3.

\begin{tabular}{|c|c|c|}
\hline \multicolumn{3}{|c|}{ N. bogotensis $(n=12)$} \\
\hline & PC 1 & PC 2 \\
\hline ONL & 0.18529 & 0.12481 \\
\hline BZP & 0.79866 & -0.51397 \\
\hline LD & 0.23801 & 0.22664 \\
\hline LIF & 0.46159 & 0.76969 \\
\hline LM1-3 & 0.1036 & -0.25169 \\
\hline BB & 0.004621 & 0.023879 \\
\hline CIL & 0.19013 & 0.07015 \\
\hline IML & 0.10575 & -0.087326 \\
\hline Eigenvalue & 0.0019788 & 0.0006965 \\
\hline$\%$ variance & 65.571 & 23.081 \\
\hline \multicolumn{3}{|c|}{ N. latebricola $(n=21)$} \\
\hline & PC 1 & PC 2 \\
\hline ONL & -0.010971 & 0.11015 \\
\hline ZB & -0.006378 & -0.025584 \\
\hline IB & 0.09867 & 0.063224 \\
\hline BZP & 0.041397 & 0.66519 \\
\hline LD & 0.15393 & 0.24007 \\
\hline BBP & 0.0086206 & 0.071494 \\
\hline LIF & 0.067016 & 0.50184 \\
\hline BIF & 0.78061 & -0.11472 \\
\hline LM1-3 & -0.096618 & 0.21955 \\
\hline BM1 & -0.12144 & 0.16342 \\
\hline BPB & 0.5329 & 0.031021 \\
\hline LN & 0.024229 & 0.089939 \\
\hline $\mathrm{BB}$ & -0.018767 & -0.077084 \\
\hline $\mathrm{BOC}$ & 0.041391 & -0.034099 \\
\hline CIL & -0.026062 & 0.19255 \\
\hline ZIL & 0.074836 & 0.088529 \\
\hline $\mathrm{MH}$ & 0.13971 & 0.20511 \\
\hline IML & -0.11945 & 0.18693 \\
\hline Eigenvalue & 0.00417 & 0.00069 \\
\hline$\%$ variance & 66.307 & 10.977 \\
\hline
\end{tabular}

der have been largely controlled by armed forces, turning mammalogical surveys an almost impossible task. Since N. latebricola is recorded in Ecuador very close to this border, and taking into account the habitat continuity (Curay 2019), its occurrence in Colombia is highly expected. The Andean geography in southern Colombia is very complex involving, towards north of Nudo de los Pastos, the occurrence of three main chains (cordilleras) instead of the two branches characterizing the Ecuadorian Andes. We could assume that contact between populations of $\mathrm{N}$. latebricola and $N$. bogotensis has been limited by factors associated with this complexity. However, the finding of a single specimen from Nariño, Pasto Municipality, (Ramírez-Chaves and
Noguera-Urbano 2010), which was erroneously identified as N. latebricola (Appendix 6), evidences that the distribution of bogotensis extends to the south of Colombia, and supports our hypothesis of reduced sampling in the region.

Neomicroxus bogotensis spatial structure and taxonomic implications. Of the two species currently considered in Neomicroxus, N. bogotensis, the smallest in body size, is the most poorly known. Almost a century after its shallow original description (Thomas 1895), N. bogotensis received some attention. Reig (1987:360) concluded, after the inspection of its holotype, that bogotensis belongs "... neither to Akodon nor to Abrothrix and that is a distinctive genus of Akodontini." In addition, provided an informal diagnosis of Microxus, the genus where he placed this form, and distinguished bogotensis by their unique diploid complement $(2 \mathrm{n}=35-37, \mathrm{FN}=$ 48; Barros and Reig 1979), and the lacking of paired ventral prostates (shared with Thaptomys, a finding conducted by Voss and Linzey 1981). The most recent descriptions of the species (Alvarado-Serrano and D'Elía 2015:98; Pardiñas and Brito 2017:409) considered this taxon as monotypic, despite previous indications in opposite way (see below).

Although stated as"rare" (see Linares 1998:272; AlvaradoSerrano and D'Elía 2015:98), N. bogotensis is an abundant cricetid in Andean highlands, at elevations between 2,400 and 3,900 masl, which corresponds to the cloud forest and páramo ecosystems (Cuatrecasas 1958; López-Arévalo et al. 1993; Rangel 2001). Ecological and systematic studies report it as an easy species to found in evergreen ombrophile montane forest and shrubby upland meadows (e. g., Reig 1986; López-Arévalo et al. 1993; Soriano et al. 1999; Ventura et al. 2000; Vianchá et al. 2012).

Originally described for the "Plains of Bogota" (Thomas 1895:369), Cundinamarca, it has also been collected in others departments associated with the Cordillera Oriental in Colombia as Boyacá, Santander, and Norte de Santander (Saénz-Jiménez 2010; Vianchá et al. 2012). Some databases of mammalian collections also list specimens, not reviewed in this contribution, from the departments of César, Tolima, and Huila (i. e., American Museum of Natural History, The Field Museum of Natural History). The record of RamírezChaves and Noguera-Urbano (2010) from the Nariño department is a significant data about the extension of the $N$. bogotensis geographic range towards southern Colombia. The range for the species is completed by its occurrence in the Cordillera de Mérida and Páramo de Tamá, in the Venezuelan states of Táchira and Mérida (AlvaradoSerrano 2005), plus an unconfirmed mention from Trujillo (Soriano et al. 1999).

Our analyses revealed a clear geographic structure in $N$. bogotensis, separating with strong support the specimens of Norte de Santander and Santander from that of Cundinamarca. Although our study has only a sequence of Cundinamarca, the high genetic distance values ( $>6 \%$ ) suggest the specific distinction of the populations from northern Colombia. This also warns about the restricted gene flow between northern departments and Cundinamarca. 
It is interesting to note that so far, no studies have evaluated populations in northern Colombia and Venezuela as a whole. Soriano et al. (1999) highlight the need to examine the taxonomic identity of the populations of $\mathrm{N}$. bogotensis in Venezuelan Andes. According to these authors, "it is convenient to examine the taxonomic identity of the populations of the latter [Neomicroxus bogotensis], in the light of the parapatric or gradient speciation model, as has been referred to by Patton et al. (1990). Thus, given its high Andean distribution pattern, we expect that the morphotype of the Cordillera de Mérida, by virtue of its possible geographical isolation, could be distinguishable from the rest of the Andean populations. In the same way, we think that the identity of the Venezuelan populations of T.[homasomys] laniger and Chilomys instans would have to be examined" (Soriano et al. 1999:22).

The Andes in northern Colombia and Venezuela have great geographical complexity characterized by some depressions (e. g., Táchira and Barquisimeto Depression) that separate the mountains and generate significant breaks that lead to isolation and formation of so-called "montane sky islands" (Reig 1986; Anderson et al. 2012). In this sense, the Táchira Depression, characterized by a dry subtropical climate, has been regarded as a biogeographical barrier to the dispersal of Andean species from both cordilleras (Cordillera Oriental de Colombia and Cordillera de Mérida, Soriano et al. 1999; Soriano et al. 2005). Species with lower vagility and strictly restricted to the cloud forest and páramo, would be virtually absent today, but probably had a wider and continuous distribution during glacial periods as suggested for Heteromys australis (Anderson and Soriano 1999) and Marmosa waterhousei (Gutiérrez et al. 2011), both species distributed in a lower altitudinal range than Neomicroxus. Based on the morphometrical results, the individuals from Venezuela are smaller (Figure 3, Table 1), clearly distinguishable from the Colombian specimens. It seems unlikely that the absence of $N$. bogotensis in the Táchira Depression is just an artifact of inadequate sampling. Probably, the current climatic conditions of this geographical barrier are too dry and would be an inadequate habitat for a typical species of cloud forest and páramo environments, which would restrict gene flow between Colombian and Venezuelan populations. In this way, a study with greater geographical coverage could favor the predictions of Soriano et al. (1999).

Our preliminary data from populations of the Norte de Santander and Santander add diversity to the current concept of $N$. bogotensis in Colombia. The high divergence level suggests a deep break between specimens from northern Colombia and Cundinamarca (the department where the type locality is placed; Thomas 1895). An important geographic barrier of this area is the Chicamocha canyon produced by the erosion of the tributary of Chicamocha river through the Boyacá and Santander departments, and it has been referred to as responsible for the allopatric speciation in some small vertebrates (e. g., Guarnizo et al. 2015; Cárdenas 2017). Unpublished data from one of the authors (JCP) also suggests a high divergence degree on cytb sequences in Cryptotis thomasi, Thomasomys niveipes and Notosciurus granatensis from both sides of this barrier.

Although $N$. bogotensis has only been formally mentioned for Cundinamarca, Boyacá and Santander departments (Saénz-Jiménez 2010; Vianchá et al. 2012), is very probably that the species occurs in the Cordillera Oriental and extends its distribution southward. In this sense, the record of Ramírez-Chaves and Noguera-Urbano (2010) from Nariño, support this assumption and suggest that the museum specimens from Tolima, Huila and Cauca would correspond to N. bogotensis. So, the gap that we observe in the distribution of this species is probably due to insufficient sampling and both Neomicroxus species would not be allopatric.

Our findings expose key points to consider in future studies: i) the diversity of $N$. bogotensis seems greater than that reflected in its current concept, ii) topographic and climatic complexity are playing an important role in the diversification of small Andean mammals being probably responsible for the observed genetic discontinuities, especially in the northern Andes of Colombia, iii) as a way of clarifying the gap observed towards southern Colombia and bordering Ecuador, is necessary to focus the sampling efforts towards regions still unexplored, iv) the review of specimens deposited in collections that were not evaluated in this work is imperative, and v) the importance of future studies that evaluate the Colombian and Venezuelan populations as a whole.

Neomicroxus latebricola spatial structure and taxonomic implications. N. latebricola was originally described from a single specimen from Tungurahua province in central Ecuador (Anthony 1924). A few additional studies have extended its distribution to include Napo, Pichincha, Imbambura, and Carchi provinces as well as revealed findings like a shallow geographical structure (Curay 2019; Voss 2003; AlvaradoSerrano 2005; Brito 2013). Additionally, Muñoz et al. (2018) determined a chromosomal number of $2 \mathrm{n}=44$, $\mathrm{FN}=42$, for specimens from Pirámides de Cochasqui, Cantón Pedro Moncayo, Pichincha province. Similar to $N$. bogotensis, N. latebricola is a common and abundant species easy to capture in Polylepis forests and páramo between 2,420 and 3,950 masl (Brito 2013;Curay 2019).

Our molecular phylogenetic analysis confirms the structure observed with the morphometric dataset, which shows a partial overlapping between specimens from along both cordilleras in Ecuador. This overlapping is reflected in the genealogical relationships between individuals from Carchi and a specimen from Napo province, which could be evidence of an area of primary or secondary contact. A primary contact zone implies the differentiation of the population in situ, while the secondary is produced by the contact of previously allopatric populations (e. g., Schneider 1996; Bertl et al. 2018). For now, our data are insufficient to distinguish between these two scenarios. 
The variation observed within N. latebricola allows to highlight two important points: i) the measurements of the specimens from Cordillera Oriental fit into the metric variation recorded by Anthony (1924) and later authors (Moreno and Albuja 2005; Alvarado-Serrano and D'Elía 2013), and ii) the potential distinction of a new subspecies for the Cordillera Occidental populations, distinguished from the nominotypic form by a summatory of craniodental traits and coloration. In fact, Curay (2019) notes variations in the dorsoventral coloration of the body and the forefoot and hindfoot, which could be related to the habitats characteristics (e. g., topography, climate, vegetation) in both cordilleras. Our geographic coverage allows us to state that $N$. latebricola in the Cordillera Occidental is a frequent species, strictly associated to forests with shrubs and trees where Polylepis incana is the dominant plant (Brito 2013). By the contrary, N. latebricola in the Cordillera Oriental occurs in the ecotonal zone between the páramo and forest whose typical vegetation is the wiry bunch grass to $1 \mathrm{~m}$ high and other larger species frequent of wooded environments (Voss 2003). The intraspecific color variation in rodents has been associated with the sex, age, seasonality, and habitat (e. g., Camargo et al. 2016; Ríos and Álvarez-Castañeda 2012; Sandoval et al. 2016). In this regard, the coloration pattern in N. latebricola seems linked with the soil and vegetation color and the exposure to be detected by predators. It varies from darker in the open habitat from the Cordillera Oriental to light brownish in the habitat with more vegetation coverage in the Cordillera Occidental.

Related to the molecular data, the shallow topology (Figure 2a), shared haplotypes, and low genetic distance values reveal the existence of current genetic flow among its populations suggesting there are no apparent geographical barriers that limit it. Contrary to what we have inferred for $N$. bogotensis populations, $N$. latebricola has experienced recent demographic expansion. These results imply that the geographic complexity of the Ecuadorian Andes is not a determining factor in the differentiation of these populations.

The presumptive existence of a new infraspecific taxon within N. latebricola implies raising the wide debate over the importance and utility of the subspecies (e. g., Wilson and Brown 1953; Endler 1977; Fitzpatrick 2010). The traditional concept involves geographic discontinuities on some morphological traits within a species as the result of ecological and historical factors, but the constant search for agreement between morphological and molecular data has led to an incorrect interpretation of what subspecies would be. Based mainly on DNA data, many authors have equated obtaining geographic structure and reciprocal monophyly, used to delineate species, as useful and appropriate ways to identify or to reject subspecies. However, this goes against the gene flow that exists between the populations of a species and that maintains them as a clear taxonomic unit. The geographic variation recovered in N. latebricola reminds us of the statement of Patton and Conroy (2019:1019) about the subspecies "... are genealogical networks of populations, often without cladistics structure..." instead the species are considered "...hierarchical units with a dichotomous branching history." This conceptual distinction is key to improve the understanding that species and subspecies are not equivalent, and that this misunderstanding has caused us to ignore or obscure the infraspecific diversity of taxa. In this case, our data clearly support the existence of a new subspecies for $N$. latebricola such a typical inhabitant of the forests of Polylepis.

Conflicts between molecular data and morphological evidence, especially the necessity to find data congruence and monophyly, and the attempt to delineate molecular clades with phenotypical features, triggered the progressive discard of infraspecific treatments and its biological value. Paradigmatic examples are abundant among Patagonian sigmodontines with prolific nominal contents (e. g., Abrothrix, Loxodontomys, Oligoryzomys, Paynomys; see Palma et al. 2010; Cañón et al. 2010; Alarcón et al. 2011; Palma and Rodríguez-Serrano 2017). Clearly, we need to reevaluate large series of specimens, looking for diagnosable patterns of size and color in accordance with geography, in a refoundational effort to recover the value of geographic races among South American cricetids.

Finally, despite the verifiable progress during last decades there is a remarkable lack of basic knowledge affecting many Andean sigmodontines (e. g., Aepeomys lugens, Chilomys instans, several Thomasomys). Neomicroxus is a crystal example for which many aspects of its natural history, ecology, biogeography and alpha taxonomy still remain unknown. Our contribution set a preliminary base for future studies evaluating the variation within the genus, as well as that of other small non-volant mammals with shared distributions. On the other hand, it exposes the importance of the subspecies concept such as nonhierarchical, nonreciprocal monophyletic, closely interbreed, and geographically structured groups.

\section{Acknowledgements}

We are proud to contribute to a memorial volume to highlight the trajectory and work of Sydney Anderson, an eminent mammalogist deeply involved with the study of the Neotropical fauna as well as several candent topics of evolutionary biology in the 60 and 70 . In this sense, we are indebted to the editors of the present series of contributions, J. Salazar Bravo and T. Tarifa. We would like to thank the curators and staff of institutions that allowed access to material, especially S. Burneo (QCAZ), M. Pinto and J. Pablo Carrera (MEPN), H. López-Arévalo and C. Cárdenas (ICN), J. Lozano and M. S. Sierra (IAvH), V. H. Serrano Cardozo (UIS-MZ), and D. Lunde (USNM). Our special gratitude to the persons that assisted us in field activities (F. Acosta, M. Gavilánez, and C. Granja). Economically, this study was supported with funds derived from INABIO (Ecuador), grant Agencia Nacional de Promoción Científica y Tecnológica 2014-1039 (to UFJP). The visit of one of the authors (UFJP) to work in Quito was funded by Fundación Ecominga and the generosity of J. Robayo. $N$. 
bogotensis UIS-MZ1596 was collected during the execution of Santander BIO, a project funded by the Sistema General de Regalías, managed by the Departmento Nacional de Planeación (BPIN2017000100046), executed by the Gobernación de Santander, and operated by the Instituto de Investigación de Recursos Biológicos Alexander von Humboldt (IAvH) and the Universidad Industrial de Santander (Inter-administrative Agreement 2243, Gobernación de Santander).

\section{Literature cited}

Alarcón, O., G. D’Elía, E. P. Lessa, and U. F. J. Pardiñas. 2011. Phylogeographic structure of the fossorial long-clawed mouse Chelemys macronyx (Cricetidae: Sigmodontinae). Zoological Studies 50:682-688.

Alvarado-Serrano, D. F. 2005. Caracterización morfométrica y distribución del género Akodon (Muridae: Sigmodontinae) en Ecuador. B.S. Thesis. Pontificia Universidad Católica del Ecuador. Quito, Ecuador.

Alvarado-Serrano, D., and G. D'Elía. 2013. A new genus for the Andean mice Akodon latebricola and A. bogotensis (Rodentia: Sigmodontinae). Journal of Mammalogy 94:995-101.

Alvarado-Serrano, D., And G. D'Elía. 2015. Genus Neomicroxus. Pp. 96-99 in Mammals of South America. Volume 2. Rodents. (Patton, J., U. F. J. Pardiñas, and G. D'Elía, eds). The University of Chicago Press. Chicago, U.S.A.

Anderson, R. P., AND P. J. Soriano. 1999. The occurrence and biogeographic significance of the southern spiny pocket mouse Heteromys australis in Venezuela. Zeitschrift Für Säugetierkunde 64:121-125.

Anderson, R. P, E. E. Gutiérrez, J. Ochoa-G, F. J. García, and M. Aguilera. 2012. Faunal nestedness and species-area relationship for small non-volant mammals in "sky islands"of northern Venezuela. Studies on Neotropical Fauna and Environment 47:157-170.

Anthony, H. E. 1924. Preliminary report on Ecuadorean mammals. American Museum Novitates 6:1-9.

Barros, M. A., and O. Reig. 1979. Doble polimorfismo robertsoniano en Microxus bogotensis (Rodentia: Cricetidae) del páramo de Mucubaji (Mérida, Venezuela). Acta Científica Venezolana 30:96.

Bertl, J., H. Ringbauer, and M. G. B. Blum. 2018. Can secondary contact following range expansion be distinguished from barriers to gene flow? PeerJ 6:e5325.

BRITo, J. 2013. Composición y abundancia de los pequeños mamíferos terrestres en dos tipos de hábitats (Páramo de Frailejón y bosque de Polylepis) en la Reserva Ecológica El Ángel, Carchi-Ecuador. Bachelor thesis, Universidad Central del Ecuador, Ecuador.

Camargo, C., E. Colares, and A. M. Castrucci. 2006. Seasonal pelage color change: news based on a South American rodent. Anais da Academia Brasileira de Ciências 78:77-86.

Cañón, C., G. D’Elía, U. F. J. Pardiñas, and E. P. Lessa. 2010. Phylogeography of Loxodontomys micropus with comments on the alpha taxonomy of Loxodontomys (Cricetidae: Sigmodontinae). Journal of Mammalogy 91:1449-1458.

Cárdenas, C. 2017. Taxonomía y distribución del género de roedores andinos: Nephelomys (Cricetidae: Sigmodontinae) en Colombia. Tesis de: Magister en Ciencias, Universidad Nacional de Colombia, Colombia.

Carleton, M. D., and G. G. Musser. 1989. Systematic Studies of Oryzomyine rodents (Muridae, Sigmodontinae): a sinopsis of Mycroryzomys. Bulletin of the American Museum of Natural History 191:1-83.

CodonCode Aligner v5.1. 2014. CodonCode Corporation. Centerville, U.S.A.

Corporación Suna Hisca. 2003. Parque Ecológico Distrital de Montaña Entrenubes, componente biofísico: Mamíferos. Departamento Técnico Administrativo del Medio Ambiente Bogotá, Colombia.

Cuatrecasas, J. 1958. Aspectos de la vegetación natural de Colombia. Revista de la Academia Colombiana de Ciencias Exactas Físicas y Naturales 10:221-268.

CuRAY, J. 2019. Caracterización morfométrica y modelamiento distribucional de Neomicroxus latebricola (Rodentia: Cricetidae) en el Ecuador. Bachelor thesis, Universidad Central del Ecuador, Ecuador.

Da Silva, M. N., and J. L. Patton. 1993. Amazonian phylogeography: mtDNA sequence variation in arboreal echimyid rodents (Caviomorpha). Molecular Phylogenetics and Evolution 2:243-255.

EndLeR, J. A. 1977. Geographic variation, speciation, and clines. Monographs in Population Biology 10:1-246.

FARRIS, J. S. 1982. Simplicity and informativeness in systematics and phylogeny. Systematic Zoology 31:413-444.

Felsenstein, J. 1981. Evolutionary trees from DNA-sequences; a Maximum-Likelihood approach. Journal of Molecular Evolution 17:368-376.

Fitzpatrick, J. W. 2010. Subspecies are for Convenience. Ornithological Monographs 67:54-61.

Giarla, T. C., R. S. Voss, AND S. A. Jansa. 2010. Species limits and phylogenetic relationships in the didelphid marsupial genus Thylamys based on mitochondrial DNA sequences and morphology. Bulletin of the American Museum of Natural History 346:1-67.

Gonçalves P. R., A. U. Christoff, L. F. Machado, C. R. Bonvicino, F. B. Peters, And A. R. Percequillo. 2018. Unraveling Deep Branches of the Sigmodontinae Tree (Rodentia: Cricetidae) in Eastern South America. Journal of Mammalian Evolution 27:139-160.

Guarnizo, C. E., A. Paz, A. Muñoz-Ortiz, S. V. Flechas, J. MéndezNarváez, and A. J. Crawford. 2015. DNA Barcoding Survey of Anurans across the Eastern Cordillera of Colombia and the Impact of the Andes on Cryptic Diversity. PLoS One 10:e0127312.

Gutiérrez, E. E., P. J. Soriano, R. V. Rossi, J. Murillo, J. Оchoa-G, and M. Aguilera. 2011. Occurrence of Marmosa waterhousei in the Venezuelan Andes, with comments on its biogeographic significance. Mammalia 75:381-386.

GyLDenstolPE, N. 1932. A manual of Neotropical sigmodont rodents. Kunglia Svenska Vetenskapsakademiens Handlingar 11:1-164.

Hammer, Ø., D. A. T. Harper, and P. D. Ryan. 2001. PAST: Paleontological Statistics Software Package for Education and Data Analysis. Palaeontologia Electronica 4:9.

Hanson, J. D., AND R. D. Bradley. 2008. Molecular diversity within Melanomys caliginosus (Rodentia: Oryzomyini). Occasional Papers, Museum of Texas Tech University 275:1-11. 
Huelsenbeck, J. P., F. Ronquist, R. Nielsen, and J. Bollback. 2001. Bayesian inference of phylogeny and its impact on evolutionary biology. Science 294:2310-2314.

IRWIN, D. M., T. D. KoCHER, AND A. C. WiLson. 1991. Evolution of the cytochrome $b$ gene of mammals. Journal of Molecular Evolution 32:128-144.

Jansa, S. A., AND R. S. Voss. 2000. Phylogenetic Studies on Didelphid Marsupials I. Introduction and Preliminary Results from Nuclear IRBP Gene Sequences. Journal of Mammalian Evolution 7:43-77.

Johnson, R. A., AND D. W. Wichern. 1999. Applied multivariate statistical analysis. Upper Saddle River, New Jersey. 67.

Kumar, S., G. Stecher, and K. Tamura. 2016. MEGA7: Molecular Evolutionary Genetics Analysis version 7.0 for bigger datasets. Molecular Biology and Evolution 33:1870-187.

Larkin, M. A., G. Blackshields, N. P. Brown, R. Chenna, P. A. McGettigan, H. McWilliam, F. Valentin, I. M. Wallace, A. WiLm, R. Lopez, J. D. hompson, T. J. GIBSon, AND D. G. HigGins. 2007. Clustal $W$ and Clustal X version 2.0. Bioinformatics 23:2947-2948.

LINARES, O. J. 1998. Mamíferos de Venezuela. Caracas: Sociedad Conservationista Audubon de Venezuela. Caracas, Venezuela.

López- Arévalo, H., O. Montenegro- Díaz, and A. Cadena. 1993. Ecología de los pequeños mamíferos de la Reserva Biológica Carpanta, en la Cordillera Oriental colombiana. Studies on Neotropical Fauna and Environment 28:193-210.

Moreno, P., And L. Albuja. 2005. Nuevos registros de Akodon orophilus (Rodentia: Muridae) en el Ecuador. Revista Politécnica 26:28-44.

Muñoz, G., J. Curay, R. Viteri, M. M. Gavilánez, J. Brito, and C. Miguel Pinto. 2018. El regreso de la citogenética de roedores al Ecuador: caracterización cariotípica de los ratones andinos Neomicroxus latebricola y Reithrodontomys soederstroemi. Pp. 116-117 in Libro de resúmenes, II Congreso Nacional de manejo de vida silvestre y IV Congreso Ecuatoriano de Mastozoología. Loja, Ecuador.

Nguyen, L. T., H. A. Schmidt, A. Von Haeseler, and B. Q. Minh. 2015. IQ-TREE: a fast and effective stochastic algorithm for estimating maximum-likelihood phylogenies. Molecular Biology and Evolution 32:268-274.

Ojala-Barbour, R., J. Brito, and W. Teska. 2019. A comparison of small mammal communities in two High-Andean Polylepis woodlands in Ecuador. Avances en Ciencias e Ingenierías 11:208-221.

Palma, R. E., E. Rodríguez-Serrano, E. Rivera-Milla, C. E. Hernández, J. Salazar-Bravo, M. I.Carma, and T. L. Yates. 2010. Phylogenetic relationships of the pygmy rice rats of the genus Oligoryzomys Bangs, 1900 (Rodentia: Sigmodontinae). Zoological Journal of the Linnean Society of London 160:551-566.

Palma, E., and E. Rodríguez-Serrano. 2017. Systematics of Oligoryzomys (Rodentia, Cricetidae, Sigmodontinae) from southern Chilean Patagonia, with the description of a new species. Journal of Zoological Systematics and Evolutionary Research 56:280-299.

Pardiñas, U. F. J., And J. Brito. 2017. Genus Neomicroxus. Pp 409 in Handbook of the Mammals of the World-Volume 7: Rodents II. (Wilson, D. E., T. E. Lacher, Jr., and R. A. Mittermeier, eds.). Lynx Editions. Barcelona, España.
Patton, J. L., P. Myers, ANd M. F. Smith. 1990. Vicariant versus gradient model of diversification: the small mammal fauna of eastern Andean slopes of Peru. Pp 355-371 in Vertebrates in the Tropics (Peters, G., and R. Hutterer, eds.). Bonn: Alexander Koenig Zoological Research Institute.

Patton, J. L., and C. J. Conroy. 2017. The conundrum of subspecies: morphological diversity among desert populations of the California vole (Microtus californicus, Cricetidae). Journal of Mammalogy 98:1010-1026.

PosadA, D. 2008. jModelTest: Phylogenetic Model Averaging. Molecular Biology and Evolution. 25:1253-1256.

Rambaut, A., A. J. Drummond, D. Xie, G. Baele, and M. A. Suchard. 2018. Posterior summarisation in Bayesian phylogenetics using Tracer 1.7. Systematic Biology 67:901-904.

Ramírez-Chaves, H. E., and E. A. Noguera-Urbano. 2010. Lista preliminar de los mamíferos (Mammalia: Theria) del departamento de Nariño, Colombia. Biota Colombiana 11:117-140.

Rangel, J. O. 2001. Elementos para una biogeografía de los ambientes de alta montaña de América Latina con especial referencia al norte de los Andes. Pp. 49-62 in Introducción a la Biogeografía en América Latina: Teorías, Conceptos, Métodos y Aplicaciones. (Llorente, J. and J. J. Morrone, eds.). Facultad de Ciencias UNAM. Ciudad de México, México.

REIG, O. 1986. Diversity patterns and differentiation of high Andean rodents. Pp. 404-40 in High Altitude Tropical Biogeography, (Vuilleumier, F., and M. Monasterio, eds.). Oxford University Press. New York, U.S.A.

REIG, O. 1987. An assessment of the systematics and evolution of the Akodontini, with the description of new fossil species of Akodon (Cricetidae: Sigmodontinae). Fieldiana: Zoolology 39:347-399.

Rıos, E., and S. T. Álvarez-Castañeda. 2012. Pelage color variation in pocket gophers (Rodentia: Geomyidae) in relation to sex, age and differences in habitat. Mammalian Biology 77:160-165.

Ronquist, F., M. Teslenko, P. Van Der Mark, D. L. Ayres, A. Darling, S. Höhna, B. Larget, L. Liu, M. A. Suchard, and J. P. Huelsenbeck. 2012. MrBayes 3.2: efficient Bayesian phylogenetic inference and model choice across a large model space. Systematic Biology 61:539-542.

Sáenz-Jiménez, F. A. 2010. Aproximación a la fauna asociada a los bosques de roble del corredor Guantiva - La Rusia Iguaque (Boyacá-Santander, Colombia). Revista Colombia Forestal 13:299-334.

Sandoval Salinas, M. L., R. M. Bárquez, E. M. Colombo, and J. D. SANDoval. 2016. Intra-specific pelage color variation in a South American small rodent species. Brazilian Journal of Biology 77:1-11.

Salazar-Bravo J., U. F. J. Pardiñas, H. Zeballos, and P. Teta. 2016. Description of a new tribe of Sigmodontinae rodents (Cricetidae: Sigmodontinae) with an updated summary of valid tribes and their generic contents. Occasional Paper Museum Texas Tech University 338:1-24.

SCHNeider, C. J. 1996. Distinguishing between primary and secondary intergradation among morphologically differentiated populations of Anolis marmoratus. Molecular Ecology 5: 239-249. 
Smith, M. F., and J. L. Patton. 1993. The diversification of South American murid rodents: evidence from mitochondrial DNA sequence data for the akodontine tribe. Biological Journal of the Linnean Society 50:149-177.

Soriano, P. J., A. Díaz de Pascual, J. Ochoa-G., and M. Aguilera. 1999. Biogeographic analysis of the mammal communities in the Venezuelan Andes. Interciencia 24:17-25.

Soriano, P. J., A. Ruiz, ANd Z. Zambrano. 2005. New noteworthy records of bats for the Andean region of Venezuela and Colombia. Mammalia 69:251-255.

Stanhope, M., J. CZelusniak, J-S. Si, J. Nickerson, and M. Goodman. 1992. A molecular perspective on mammalian evolution from the gene encoding Interphotoreceptor Retinoid Binding Protein, with convincing evidence for bat monophyly. Molecular Phylogenetics and Evolution 1:148-160.

Steppan, S. J., R. M. Askins, And J. Anderson. 2004. Phylogeny and divergence-date estimates of rapid radiations in muroid rodents based on multiple nuclear genes. Systematic Biology 53:533-553.

Swofford, D. L. 2000. PAUP*: Phylogenetics Analysis Using Parsimony (*and Other Methods). Ver. 4.0. Computer software and manual. Sinauer Associates, Inc. Publishers. Sunderland, U.K.

Tномаs, O. 1895. On small mammals from Nicaragua and Bogota. Annals and Magazine of Natural History 6:55-60.

Trifinopoulos, J., L. T. Nguyen, A. von Haeseler, and B. Q. Minh. 2016. W-IQ-TREE: a fast online phylogenetic tool for maximum likelihood analysis. Nucleic Acids Research 44:232-235.

Ventura, J., M. J. López-Fuster, M. Salazar, and R. PérezHernandez. 2000. Morphometric analysis of some Venezuelan akodontine rodents. Netherlands Journal of Zoology 50: 487-501.

Vianchá Sánchez, A., J. Cepeda-Gómez, E. Muñoz López, A. Hernández Ochia, and L. Rosero Lasprilla. 2012. Mamíferos pequeños no voladores del Parque Natural Municipal Ranchería, Paipa, Boyacá, Colombia. Biodiversidad Neotropical 2:37-44.

Voss, R. S. 2003. A new species of Thomasomys (Rodentia: Muridae) from eastern Ecuador, with remarks on mammalian diversity and biogeography in the Cordillera Oriental. American Museum Novitates 3421:1-47.

Voss, R., AND A. V. Linzey. 1981. Comparative Gross Morphology of Male Accessory Glands among Neotropical Muridae (Mammalia: Rodentia) with Comments on Systematic Implications. Miscellaneous publications Museum of Zoology, University of Michigan 159:1-41.

Wilson, E. O, AND W. L. Brown. 1953. The subspecies concept and its taxonomic application. Systematic Biology 2:97-111.

Associated editor: Jorge Salazar-Bravo

Submitted: April 5, 2020; Reviewed: April 24, 2020;

Accepted: June 10, 2020; Published on line: August 22, 2020.

\section{Appendix 1}

Specimens examined in the morphologic and genetic analyses. Genbank access numbers of the five sequenced specimens in this study are indicated in bold. * Cytb, ${ }^{* *}$ IRBP

N. bogotensis: COLOMBIA: 1) Boyacá, Municipio Guacamayas, vereda Alfaro, sitio Piedras Blancas 6.416, -72.505 (ICN 14722). 2) Cundinamarca, Junín, Reserva Biológica Carpanta 4.563, -73.683 (ICN 11027, ICN 11028, ICN 11029). 3) Cundinamarca, PNN Chingaza (IAvH 5777 - MT240521*). 4) Nariño, Pasto, aproximadamente $15 \mathrm{~km}$ carretera Pasto-Mocoa, páramo, cabaña La Pastora 0.866, -77.316 (ICN13284). 5) Norte de Santander, Cucutilla, Sisavita, Romeral, Predio Greystar [no coordinates] (UIS-MZ 907). 6) Santander, Santa Bárbara, Páramo del Almorzadero, Vereda Volcanes 7.076, -72.848 (UIS-MZ 1596 - MT240520* MT249798**). 7) Santander, Santa Bárbara, Vereda Esparta 7.019, -72.892 (UIS-MZ 1299 - MT240522* MT249797**), VENEZUELA: 8) Mérida, Tabay, 7 Km SE Tabay, La Coromoto 8.6, -71.02 (USNM 374611, USNM 374612, USNM 374613).

N. latebricola: ECUADOR: 1) Carchi, Espejo, La Libertad, Sector Bosque de Polylepis 0.712202, -77.981639, 3650 (MECN 3717-19, 3727 - MT240523* MT249799**, 3734 MT240524* MT249800**, 3735-36, 3739-40, 3748, 437677; QCAZ 11142, 11158, 11145, 12504, 12503, 9814; MEPN 10869, 10870, 10887, 10886, 12716, 10644, 12718, 12715B, 10485, 12712, 12715). 2) Carchi, Tulfán, Tufiño, Páramo del Artesón, Comuna La Esperanza (QCAZ 9801). 3) Imbabura, Pimampiro, Mariano Acosta, Laguna Blanca 0.22367, -77.97867, 3400 msnm (MECN 4763). 4) Imbabura, Zuleta, Faldas del Imbabura 0.248372, -78.15425, 3610 msnm (MECN 6134-36). 4) Imbabura, Cotacachi, Bosque Protector Neblina 0.342024, -78.412935, 2990 msnm (MECN 560506). 5) Napo, Quijo, bosque administrado por la fundación TERRA -0.33422, -78.1433, 3400 msnm (QCAZ 4090, 4121, 4160, 4167, 5230, 5236, 5239). 6) Tunguragua, Pisayambo, km. Parque Nacional Llanganates $-1.044686,-78.345828$, 3102 msnm (CNP 6396 - MECN 1739). 


\section{Appendix 2}

List of taxa for which DNA sequences were included in the phylogenetic analysis. GenBank accession numbers and vouchers for mitochondrial and nuclear genes are indicated.

\begin{tabular}{|c|c|c|c|c|}
\hline \multirow[b]{2}{*}{ Species } & \multicolumn{2}{|c|}{ Cytochrome b } & \multicolumn{2}{|c|}{ IRBP } \\
\hline & $\begin{array}{l}\text { Access } \\
\text { number }\end{array}$ & Voucher & $\begin{array}{l}\text { Access } \\
\text { number }\end{array}$ & Voucher \\
\hline Abrawayaomys chebezi & KR069109 & CG184 & MN969035 & CG184 \\
\hline Abrawayaomys ruschii & JX949189 & MN67557 & JX949185 & MN67557 \\
\hline Abrothrix hirta & U03530 & MVZ154494 & KC953347 & MVZ154494 \\
\hline Aegialomys xanthaeolus & EU074632 & TK135790 & EU273420 & TK135790 \\
\hline Aepeomys lugens & --- & --- & DQ003722 & MNHN4350 \\
\hline Akodon boliviensis & M35691 & MVZ171607 & KC953351 & FMNH162747 \\
\hline Amphinectomys savamis & EU579480 & MV97005 & AY163579 & MV970045 \\
\hline Andalgalomys pearsoni & JQ434418 & MSB80512 & JQ434398 & MSB80512 \\
\hline Andinomys edax & JQ434419 & MSB70545 & JQ434399 & MSB70545 \\
\hline Arvicola terrestris & AY275106 & MVZ155884 & AY277407 & MVZ155884 \\
\hline Auliscomys sublimis & JQ434421 & MSB75260 & JQ434402 & MSB75260 \\
\hline Baiomys musculus & EF989933 & ROM97641 & KC953360 & ROM JM48 \\
\hline Bibimys labiosus & DQ444329 & MN62062 & AY277436 & MN62062 \\
\hline Blarinomys breviceps & AY275112 & СІт1391 & AY2774337 & СІт1391 \\
\hline Brucepattersonius soricinus & AY277486 & MVZ183036 & AY277438 & MVZ183250 \\
\hline Calassomys apicalis & JQ434425 & GDE2012 & KX431561 & $?$ \\
\hline Calomys laucha & AY033190 & NK72376 & JQ434404 & MSB80539 \\
\hline Castoria angustidens & EF622508 & $?$ & KF815411 & MN78921 \\
\hline Cerradomys subflavus & EU579481 & MNRJ61885 & AY163626 & MNRJ61665 \\
\hline Chelemys megalonyx & DQ309559 & NK109208 & EU091259 & NK109253 \\
\hline Chilomys instans & AF108679 & JLP16693 & -- & --- \\
\hline Chinchillula sahamae & JQ434422 & MSB75154 & JQ434409 & MSB75254 \\
\hline Clethrionomys gapperi & AY309431 & $?$ & AY326080 & UMMZ162467 \\
\hline Cricetulus longicaudatus & KM067270 & $?$ & AY326082 & USNM449102 \\
\hline Cricetus cricetus & AJ490302 & $?$ & AY277410 & MVZ155880 \\
\hline Delomys dorsalis & KF317031 & $\mathrm{JFV} 226$ & KC953369 & MVZ182789 \\
\hline Deltamys kempi & AY195862 & MNHN4151 & AY277444 & MNHN4151 \\
\hline Drymoreomys albimaculatus & EU579487 & MVZ182088 & EU649042 & MVZ182088 \\
\hline Eligmodontia typus & AF108692 & MVZ182681 & AY277445 & MVZ182681 \\
\hline Eremoryzomys polious & EU579483 & FMNH129243 & AY163624 & FMNH129243 \\
\hline Euneomys chinchilloides & AY275115 & UP LB018 & AY277446 & UPLB018 \\
\hline Euryoryzomys macconnelli & GU126538 & AMNH272669 & AY163620 & AMNH272678 \\
\hline Galenomys garleppi & JQ434423 & AMNH262814 & JQ434410 & AMNH262814 \\
\hline Geoxus valdivianus & AY275116 & CAV001 & AY277448 & CAV001 \\
\hline Graomys griseoflavus & AY275117 & UP278 & AY277449 & UP278 \\
\hline Handleyomys alfaroi & EU579489 & TK93700 & EU649044 & TK93700 \\
\hline Handleyomys intectus & EU579490 & CADV088 & AY163584 & ICN16093 \\
\hline Holochilus brasiliensis & GU126517 & GD081 & AY163585 & GD081 \\
\hline Hylaeamys megacephalus & EU579499 & MHNLS8061 & AY163621 & MHNLS8061 \\
\hline Irenomys tarsalis & U03534 & MVZ155839 & AY2774450 & MVZ155839 \\
\hline Isthmomys pirrensis & DQ836298 & $?$ & EF989847 & ROM116309 \\
\hline Juliomys pictipes & FJ026733 & TK145073 & KC953385 & MVZ182079 \\
\hline Juscelinomys huanchacae & AY275119 & LHE1617 & AY277452 & LHE1616 \\
\hline Kunsia tomentosus & AY275121 & LHE1620 & KC953386 & USNM584516 \\
\hline Lenoxus apicalis & U03541 & MVZ171512 & KC953388 & MVZ171512 \\
\hline Loxodontomys micropus & AY275122 & EPU001 & AY2774457 & EPU001 \\
\hline Lundomys molitor & JQ966241 & MCNU2302 & JQ966805 & MCNU2302 \\
\hline Megalomys desmarestii & LN810053 & NHMUK1850 & --- & --- \\
\hline Melanomys caliginosus & EU340020 & TK135894 & KC953397 & USNM464387 \\
\hline Mesocricetus auratus & AM904612 & MauCytb06 & AY163591 & $?$ \\
\hline Microakodontomys transitorious & --- & --- & EU649054 & MN25969 \\
\hline Microryzomys minutus & AF108698 & MVZ173975 & AY163592 & MVZ166666 \\
\hline Microtus californicus & EF506105 & MVZ216595 & KC953401 & MVZ207423 \\
\hline Myospalax aspalax & AF326272 & $?$ & AY326097 & MSB100576 \\
\hline
\end{tabular}

Necromys amoenus

Nectomys squamipes

Neomicroxus bogotensis

Neomicroxus bogotensis

Neomicroxus bogotensis

Neomicroxus latebricola

Neomicroxus latebricola

Neomicroxus latebricola

Neomicroxus latebricola

Neomicroxus latebricola

Neomicroxus latebricola

Neotoma floridana

Neotomys ebriosus

Nephelomys albigularis

Nesomys rufus

Nesoryzomys swarthi

Neusticomys monticolus

Nyctoms sumichrasti

Oecomys concolo

Oligoryzomys fulvescens

Onychomys leucogaster

Oreoryzomys balneator

Oryzomys palustris

Ototylomys phyllotis

Oxymycterus nasutus

Paynomys macronyx

Pennatomys nivalis

Peromyscus leucopus

Phaeomys ferrugineus

Phodopus sungorus

Phyllotis xanthopygus

Podoxymys roraimae

Pseudoryzomys simplex

Punomys kofordi

Reithrodon auritus

Reithrodontomys fulvescen

Rhagomys longilingua

Rheomys raptor

Rhipidomys macconnelli

Salinomys delicatus

Scapteromys tumidus

Scolomys ucayalensis

Scotinomys teguina

Sigmodon hispidus

Sigmodontomys alfari

Sooretamys angouya

Tanyuromys aphrastus

Tapecomys wolffsohni

Thalpomys cerradensis

Thaptomys nigrita

Thomasomys aureus

Transandinomys talamancae

Tylomys nudicaudus

Wiedomys pyrrhorhinos

Wilfredomys oenax

Zygodontomys brevicau

\begin{tabular}{|c|c|c|c|}
\hline EU579504 & MVZ155014 & AY163597 & MVZ155014 \\
\hline AY273911 & MVZ171563 & AY277458 & MVZ171569 \\
\hline GU126522 & FMNH141632 & EU273419 & TK63841 \\
\hline MT240520 & UIS-MZ 1596 & MT249798 & UIS-MZ 1596 \\
\hline MT240521 & IAvH5777 & --- & -- \\
\hline MT240522 & UIS-MZ 1299 & MT249797 & UIS-MZ 1299 \\
\hline HQ731489 & QCAZ4121 & --- & -- \\
\hline HQ731488 & QCAZ9801 & -- & -- \\
\hline HQ731490 & QCAZ4167 & KF437367 & QCAZ4167 \\
\hline KF437365 & QCAZ4160 & KF437366 & QCAZ4160 \\
\hline MT240523 & MECN3727 & MT249799 & MECN3727 \\
\hline MT240524 & MECN3734 & MT249800 & MECN3734 \\
\hline AF294344 & TK52115 & КС953411 & OSU OK 107 \\
\hline JQ434424 & MSB87134 & JQ434413 & MSB87134 \\
\hline EU579505 & AMNH268125 & AY163614 & AMNH268125 \\
\hline AF160592 & Nruf508 & AY326099 & FMNH151915 \\
\hline EU340014 & ASNHC10003 & AY163601 & ASNHC10003 \\
\hline KF359515 & ACUNHC900 & KR105605 & QCAZ6531 \\
\hline AY195801 & TK101875 & KC953421 & MSB45815 \\
\hline JF693876 & MVZ155005 & KC953424 & MVZ192947 \\
\hline GU126529 & AMNH257262 & AY163611 & AMNH257262 \\
\hline EF989959 & ROM114892 & EF989860 & ROM114892 \\
\hline EU579510 & AMNH268144 & AY163617 & AMNH268144 \\
\hline GU126539 & TTU75311 & AY163623 & TTU75311 \\
\hline AY009789 & FN32783 & КС953429 & ROM35529 \\
\hline EF661854 & $?$ & AY277468 & MVZ182701 \\
\hline U03533 & MVZ155800 & AY277441 & MVZ155800 \\
\hline LN810055 & B5 534 & --- & --- \\
\hline EF989979 & ROM101861 & EF989880 & ROM101861 \\
\hline KM065876 & MZUFV3400 & KM065877 & MZUFV3400 \\
\hline AJ973390 & $?$ & KC953439 & $?$ \\
\hline U86833 & MFS1324 & AY163632 & MVZ182703 \\
\hline KM816650 & PK3335 & KM816651 & PK3335 \\
\hline GU126547 & GD065 & AY163633 & GD065 \\
\hline JQ434426 & VPT 1890 & JQ434414 & VPT1890 \\
\hline EU579474 & MVZ182704 & AY163634 & MVZ182704 \\
\hline EF990003 & ROM114901 & EF989904 & ROM114901 \\
\hline KY754141 & $?$ & DQ003723 & FMNH175218 \\
\hline KJ921706 & KU159017 & KC953451 & ROM101294 \\
\hline AY275130 & MVZ 160082 & AY277474 & MVZ160082 \\
\hline EU377608 & OMNH23602 & JQ434415 & OMNH23602 \\
\hline AY275133 & MVZ183269 & AY277477 & MVZ193269 \\
\hline EU579518 & AMNH272721 & AY163638 & AMNH272721 \\
\hline AF108705 & UMMZ3373 & AY277415 & MVZ191230 \\
\hline AF425227 & TK90616 & AY277479 & NK27055 \\
\hline EU074635 & USNM449895 & AY163641 & USNM449895 \\
\hline GU126534 & MNRJ50234 & KC953456 & MVZ192961 \\
\hline JF693877 & KU161003 & JF693878 & KU161003 \\
\hline U86834 & MSB67270 & KC953460 & MSB63364 \\
\hline AY273916 & MZUSP30397 & AY277480 & MZUSP 30400 \\
\hline AF108666 & MVZ183044 & AY277482 & MVZ183044 \\
\hline U03540 & MVZ170076 \& 166714 & AY277483 & MVZ170076 \\
\hline GU126544 & USNM449894 & KC953465 & MSB91815 \\
\hline DQ179812 & TK41551 & AY163643 & ROM103590 \\
\hline EU579477 & MVZ197566 & AY277485 & MVZ197567 \\
\hline KJ663726 & UFSM619 & KJ663727 & MCNU2025 \\
\hline GU126549 & AMNH257321 & AY163645 & AMNH257321 \\
\hline
\end{tabular}




\section{Appendix 3}

Genetic divergence values ( $p$ distance) among cytochrome b sequences of Neomicroxus.

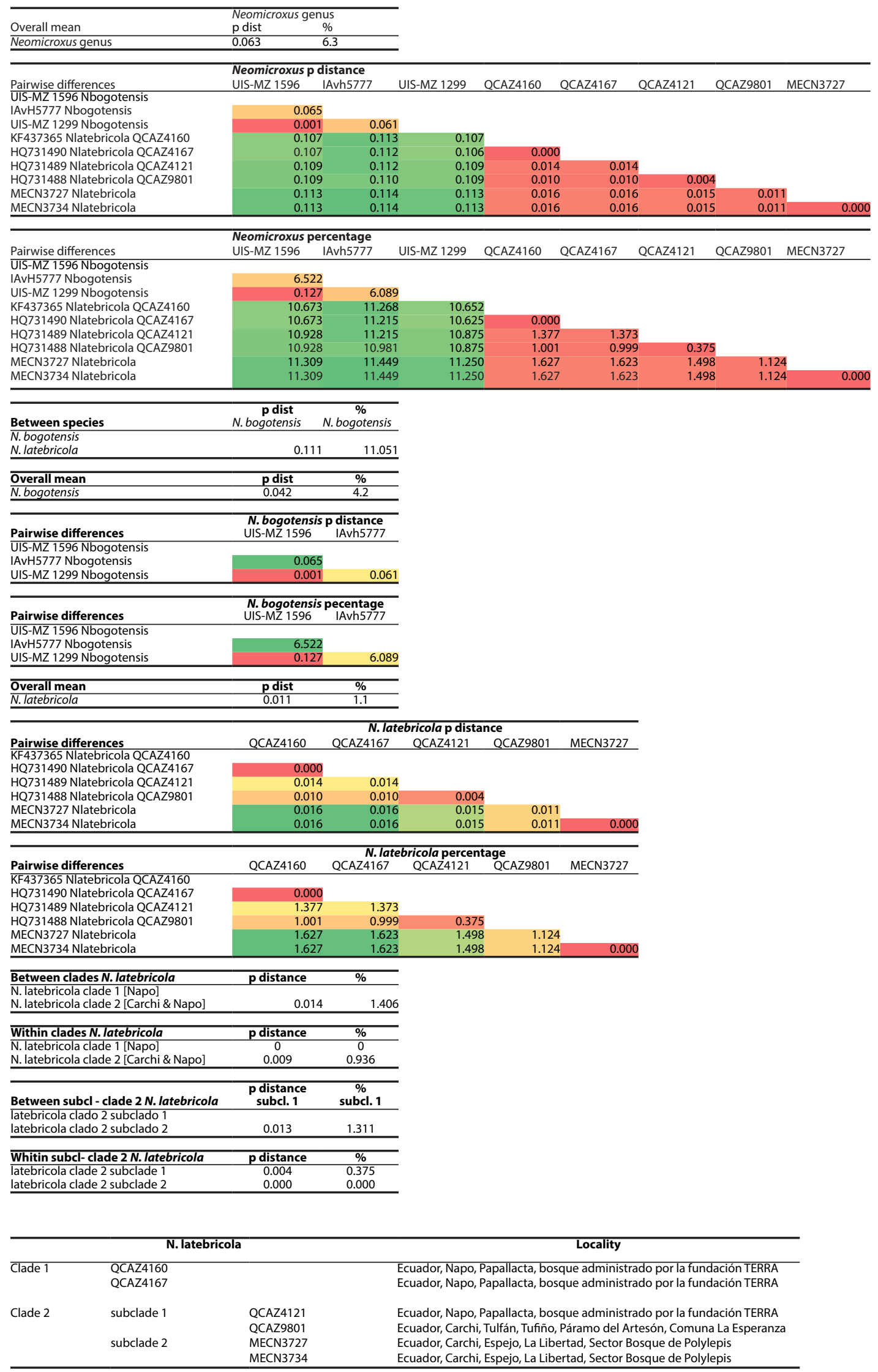




\section{Appendix 4}

Linear measurements used in descriptive, univariate, and multivariate analyses.
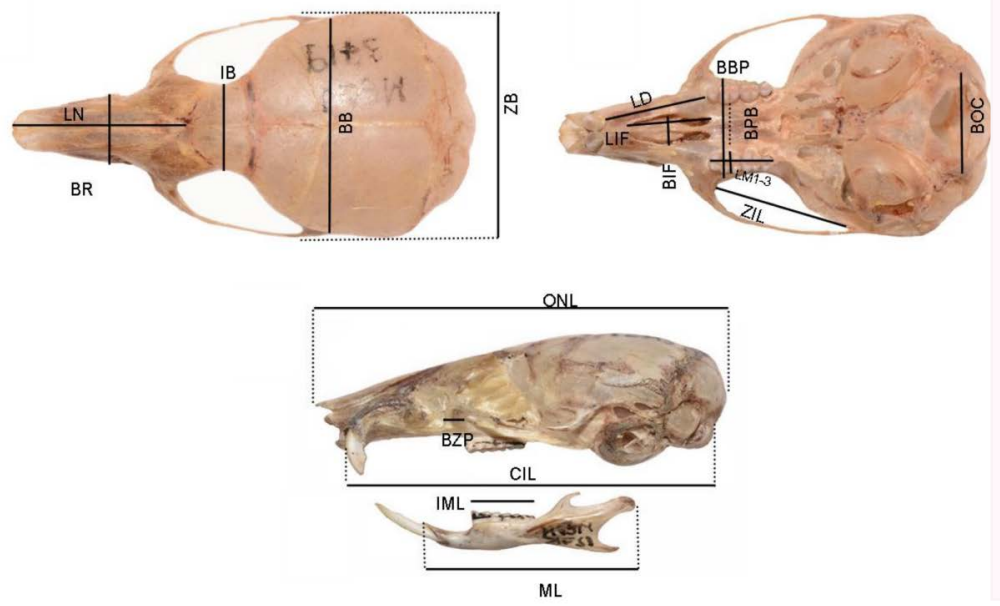

BB Breadth of braincase, BIF Breadth of incisive foramina, BM Breadth of first upper molar, BBP Breadth of bony palate, BPB Breadth of palate bridge, BOC Breadth of the occipital condyles, BZP Breadth of zygomatic plate, CIL Condyloincisive length, IB Interorbital breadth, IML Mandibular molar toothrow length, LD Length of upper diastema, LIF Length of incisive foramina, LM1-3 Length of maxillary toothrow, LN Length of nasals, ML Mandibular length, ONL Occipitonasal length, ZB Greatest zygomatic breadth, ZIL Zygomatic internal length.

\section{Appendix 5}

Groups classification achieved in the discriminant analysis with jackknife resampling.

\begin{tabular}{|c|c|c|c|c|c|c|c|}
\hline & \multicolumn{3}{|l|}{ N. latebricola } & \multicolumn{4}{|l|}{ N. bogotensis } \\
\hline & Occidente & Oriente & & North Colombia & Cundinamarca & Total & \\
\hline N. latebricola & & & & & & & \\
\hline Occidente & 11 & & 1 & 1 & & 0 & 13 \\
\hline Oriente & 2 & & 6 & 0 & & 0 & 8 \\
\hline N. bogotensis & & & & & & & \\
\hline North Colombia & 0 & & 0 & 1 & & 2 & 3 \\
\hline Cundinamarca & 0 & & 0 & 1 & & 0 & 1 \\
\hline Total & 13 & & 7 & 3 & & 2 & 25 \\
\hline
\end{tabular}

\begin{tabular}{|c|c|c|c|c|c|c|c|c|}
\hline & \multicolumn{3}{|c|}{ N. latebricola } & \multicolumn{5}{|l|}{ N. bogotensis } \\
\hline & Occidente & Oriente & & North Colombia & Cundinamarca & Venezuela & Total & \\
\hline \multicolumn{9}{|l|}{ N. latebricola } \\
\hline Occidente & & 11 & 2 & 0 & & 0 & 0 & 13 \\
\hline Oriente & & 2 & 6 & 0 & & 0 & 0 & 8 \\
\hline \multicolumn{9}{|l|}{ N. bogotensis } \\
\hline North Colombia & & 0 & 0 & 0 & & 0 & 3 & 3 \\
\hline Cundinamarca & & 0 & 0 & 0 & & 1 & 1 & 1 \\
\hline Venezuela & & 0 & 0 & 1 & & 1 & 7 & 9 \\
\hline Total & & 13 & 8 & 1 & & 1 & 11 & 34 \\
\hline
\end{tabular}




\section{Appendix 5}

Craniodental anatomy in a specimen referred as Neomicroxus bogotensis (ICN13284; previously mentioned as N. latebricola by Ramírez-Chaves and Noguera-Urbano 2010) from Nariño department, Colombia: a, cranium in palatal view; b, right half of the cranium in dorsal view; $c$, lacrimal region; $d$, zygomatic plate region in lateral view; e, left upper molars in occlusal view; $f$, left lower molars in occlusal view; $g$, auditory region in lateral view. Abbreviations: ab: auditory bulla (ectotympanic), fr: frontal, fs: frontal sinus, if: incisive foramen, l: lacrimal, mal: malleus, man: manubrium, m: maxillary, ms: maxillary septum, $\mathrm{n}$ : nasal, oap: orbicular apophysis, pal: palatine, pgf: postglenoid foramen, pm: premaxillary, sf: subsquamosal fenestra, tt: tegmen tympani, zn: zygomatic notch, zp: zygomatic plate.

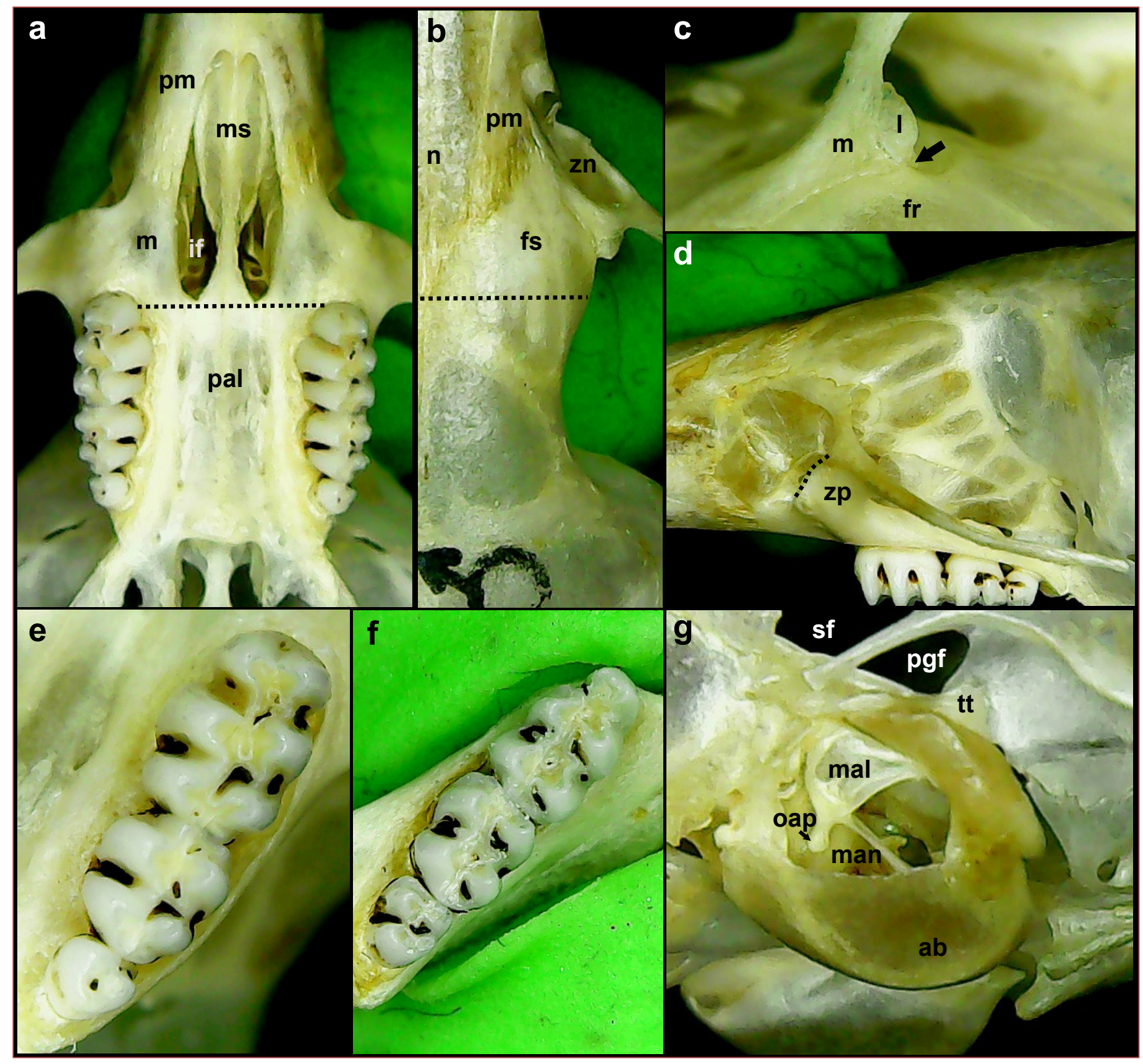

